Aykutlu, I., Bezen, S., \& Bayrak, C. (2019). An Examination of Pre-Service Teachers' Metaphorical Perceptions Concerning Physics Lab Applications. Bartin University Journal of Faculty of Education, 8(1), 32-53

Bartın UniversityJournal of Faculty of Education, 8(1), 32-53

Bartın Üniversitesi Eğitim Fakültesi Dergisi, 8(1), 32-53

buefad.bartin.edu.tr

\title{
An Examination of Pre-Service Teachers' Metaphorical Perceptions Concerning Physics Lab Applications
}

\author{
Iş11 Aykutlu*a, Sevim Bezen ${ }^{\mathrm{b}}$, Celal Bayrak ${ }^{\mathrm{c}}$
}

\begin{tabular}{l} 
Article Info \\
\hline DOI: $10.14686 /$ buefad.463841 \\
\hline Article History: \\
Received 25.09.2018 \\
Accepted 22.10 .2018 \\
Published $\quad 01.02 .2019$ \\
\hline Keywords: \\
Pre-service physics teachers, \\
Physics lab, \\
Metaphor, \\
Views of pre-service teachers. \\
\\
\hline Article Type: \\
Research article \\
\hline
\end{tabular}

\begin{abstract}
This study aimed to determine pre-service physics teachers' perceptions concerning "Physics lab application." Realized by employing phenomenology pattern, which is one of the qualitative research methods, this study aimed to reach into the life, thoughts, and perceptions of each individual which they have created through their own experience. Study group consists of 46 pre-service teachers enrolled at the department of physics education at the Faculty of Education of a state university in Ankara during the 2015-2016 academic year; and these pre-service teachers have successfully completed at least two lab classes. Data of the study were gathered via the "Physics Lab Application Metaphors Form," which is designed by the researchers, and interviews were held with pre-service teachers on the metaphors obtained through this form. Data analysis and evaluation were realized by content analysis. At the end of the study, it was determined that metaphors expressed by preservice teachers fall mostly under the conceptual category of learning through visual impact. At the same time, these pre-service teachers indicated that they had a good time during lab applications, they learn by doing/experiencing, and that they could concretize abstract concepts with the help of visuals.
\end{abstract}

\section{Öğretmen Adaylarının Fizik Laboratuvar Uygulamasına İlişkin Metaforik Algılarının İncelenmesi}

\begin{tabular}{|c|c|}
\hline \multicolumn{2}{|c|}{ Makale Bilgisi } \\
\hline \multicolumn{2}{|c|}{ DOI: 10.14686/buefad.463841 } \\
\hline \multicolumn{2}{|c|}{ Makale Geçmişi: } \\
\hline Geliş & 25.09 .2018 \\
\hline Kabul & 22.10 .2018 \\
\hline Yayın & 01.02 .2019 \\
\hline \multicolumn{2}{|c|}{$\begin{array}{l}\text { Anahtar Kelimeler: } \\
\text { Fizik öğretmen adayları, } \\
\text { Fizik laboratuvarı, } \\
\text { Metafor, } \\
\text { Öğretmen adayı görüşleri. }\end{array}$} \\
\hline \multicolumn{2}{|c|}{$\begin{array}{l}\text { Makale Türü: } \\
\text { Araştırma makalesi }\end{array}$} \\
\hline
\end{tabular}

\begin{abstract}
$\ddot{O} z$
Araştırmada fizik öğretmen adaylarının "Fizik laboratuvar uygulaması" ile ilgili algılarının belirlenmesi amaçlanmıştır. Nitel araştırma yöntemleri içerisinde yer alan olgu bilim deseninden yararlanılarak gerçekleştirilen araştırmada, her bir bireyin kendi deneyimleri ile oluşturduğu yaşam dünyasına, düşüncelerine ve algılarına ulaşılmak istenmiştir. Araştırmanın çalışma grubunu 2015-2016 eğitim ve öğretim yılında Ankara'da bulunan bir devlet üniversitesinin eğitim fakültesinin fizik öğretmenliği bölümünde öğrenim görmekte ve en az iki laboratuvar dersini alarak başarılı bir şekilde tamamlamış olan 46 öğretmen adayı oluşturmaktadır. Araştırmanın verileri araştırmacılar tarafindan hazırlanan "Fizik Laboratuvar Uygulaması Metaforlar Formu" aracılığıyla toplanmış ve elde edilen metaforlara yönelik öğretmen adayları ile görüşmeler yapılmıştır. Araştırmada verilerin çözümlenmesi ve yorumlanması içerik analizi ile gerçekleştirilmiştir. Araştırmanın sonucunda öğretmen adayları tarafından ifade edilen metaforların çoğunluğunun görsel etkiyle öğrenme kavramsal kategorisi altında yer aldığı saptanmıştır. Bu kategoriyi emek vererek öğrenme ve eğlenerek ögrenme kavramsal kategorileri takip etmektedir.
\end{abstract}

\footnotetext{
*Corresponding Author: aykutlu@ hacettepe.edu.tr

a Assoc. Prof. Dr., Hacettepe University, Ankara/Turkey, http://orcid.org/0000-0003-4068-0453

${ }^{b}$ Res. Assist., Hacettepe University, Ankara/Turkey, http://orcid.org/0000-0002-0304-5314

'Prof. Dr., Hacettepe University, Ankara/Turkey, http://orcid.org/0000-0002-9269-2029
} 


\section{Introduction}

With the rapid advancement of science and technology, it is also expected in every country that there should be constant development in terms of science and technology as well. This level of advancement can show differences based on education. Education provides qualified human resource, improves the thought capacities, knowledge, and comprehension of individuals (Collette \& Chiapetta, 1989). In the same vein, a quality education aims to train individuals who would be the means of adapting to the developments in science and technology (Yalım, 2002). In this respect, specifically science education provides individuals with such skills as reaching knowledge, comprehension, learning by doing/experiencing, and active participation in the learning process (Sarı, 2013). Science consists of all scientific knowledge that exists to meet the needs of human beings from the very beginning to this day (Çilenti, 1985). Through science technology develops, and thus society improves. With science education, the aim is to train individuals who are well-versed in understanding and interpreting technological developments. It is known that laboratories play an important role in science education in raising individuals who are in tune with science and technology (Çepni, Ayas, Johnson \& Turgut, 1997), because laboratories make it possible to learn by doing and experiencing. Indeed, laboratories are an indispensible part of education. Lab environments give the chance to students to relate what they learn with daily life, to actively participate in topics, and to structure knowledge (Tatar, Korkmaz \& Şaşmaz Ören, 2007). In short, laboratories are highly important within science education (Yenice, 2005). Due to their nature, concepts and topics within science education have a multidisciplinary aspect. These disciplines are physics, chemistry, and biology. In these disciplines it is equally important to enable students to learn by doing and experiencing so that meaningful learning takes place. In this respect, it can be argued that labs are effective factors too in physics education, which is the focus of this study (Lawson, 1995). Lab applications in physics education enable permanent and meaningful learning and make it possible to have group studies (Kesercioğlu \& Aydoğdu, 2005). In laboratories theoretical knowledge turns into a practical one, students get experience, and their hand skills are improved (Ayas, 2006). Seen from this perspective, it is obvious that laboratories are an indispensible part of science education in general and physics education in particular. Moreover, it is thought that it is imperative to use lab applications in order for physics classes to be understood and for physics education to be effective and permanent (Sar1, 2013). In literature, it is indicated that lab applications have a significant part in education although they are not used in an effective way (Alpaut, 1993; Ekici, 1996). Negative views on lab applications usually focus on how there is not enough knowledge and skills concerning labs and on how lab applications are problematic (Çallıca et al., 2001). Thus, pre-service teachers play an important role in the effective realization of lab applications appropriate to their purpose in our country. It is thought that pre-service teachers can bring a solution to the present problem, and that this can be carried to the next generations. In this study, the aim is to reveal pre-service teachers' views on physics lab applications so that an evaluation of lab applications can be done and this evaluation can be a source of information for the field. Metaphors were used to reveal pre-service teachers' perceptions. Metaphors denote linguistic tools that explain events. Through metaphors one can reveal people's perceptions (Arnett, 1999). Realities are conceptualized by the individuals by re-defining them (Goldstein, 2005). Therefore, analyzing metaphors contribute to determining how concepts are perceived (Cerit, 2008). In the department at which preservice teachers are enrolled, there are six different physics lab classes, namely, mechanics, electrics and magnetism, electronics, vibrations and waves, optics, and modern physics. In the study, physics lab application denotes physics lab classes. As a result, these six application classes were defined under the title physics lab applications by the researcher. The aim is to reveal pre-service teachers' perceptions concerning physics labs by determining their metaphors related to "Physics lab application."

\section{The Aim and Importance of the Study}

Effective and permanent learning in physics education can happen when students learn concepts by making sense of them instead of memorizing them. Meaningful learning can be defined as relating previous knowledge with the new ones and re-structuring them. The aim in physics education with effective, permanent, and meaningful learning is to create a teaching environment in which students are active participants in the process and an environment in which their success levels increase. In this respect, when it is thought that lab applications make it possible for theoretical knowledge to be learned by making sense of them, it is obvious that this application provides permanency for knowledge and that it is highly important in physics education. It is generally known that students regard concepts in physics classes as difficult to learn and they see physics classes as formula based. It was determined by various studies that students find it difficult to visualize concepts mentally and that these difficulties result in misconceptions (Halloun, 1997). With lab applications, the aim is to enable students to explore 
concepts and to paint a picture of events (Bozkurt \& Sarıkoç, 2008). It can be said that lab applications are effective on pre-service teachers' problem solving, cognitive process, and critical thinking skills in addition to increasing their academic success and attitudes (Akben, 2011; Hodson, 1988; Hofstein, Navon, Kipnis \& Mamlok, 2005). At the same time, it is believed that with lab applications, it is possible to raise inquisitive and critical pre-service teachers. In literature, it is emphasized that lab applications are at the center of science education and that it is beneficial to have such an education (Pickering, 1980; Hofstein \& Lunetta, 2003; Tobin, 1990). Lab studies are handled in literature as being beneficial for the field for conceptual and effective learning, for providing technical and research skills (Boud et al., 1986; Garnet \& O’Loughlin, 1989; Woolnough, 1991; Garnett, Garnett \& Hackling, 1995). As the importance of lab applications are underlined in such studies, it can be argued that faculties of education play a significant role in the development of students who know how to reach scientific knowledge by using lab applications. Perceptions of pre-service teachers, who have been trained in faculties of education, are important. Since the basis of a good physics education is lab applications (Yener, 2010), the aim in this study is to determine pre-service physics teachers' perceptions of lab applications through metaphors.

It is believed that findings of this study will contribute to literature. To this end, answers to following questions were sought:

1. Which metaphors did pre-service teachers generate concerning physics lab application?

2. Under which conceptual category do the physics lab application metaphors of pre-service physics teachers fall in terms of their common characteristics?

3. Is there any difference in the metaphors generated by pre-service physics teachers according to the classes they attend?

\section{Method}

\section{Research Pattern}

In the study, phenomenology pattern, which is a qualitative research method, was used in order to examine pre-service physics teachers' metaphorical perceptions concerning "Physics lab application." Through phenomenology pattern, it is possible to access the world, thought, and perception of each individual that they have formed by their experience (Christensen, Johnson \& Turner, 2011). Likewise, phenomenology makes it possible to reveal how individuals make sense of their experience, how they transfer it to their minds, how they categorize and evaluate it (Patton, 2014). Phenomenology is a pattern which makes it possible to focus on concepts that we are aware of but no in complete and thorough understanding of (Creswell, 2003). That is why phenomenology pattern was employed in this study.

\section{Study Group}

Study group consists of pre-service teachers who are enrolled at the physics education department at a state university in Ankara in 2015-2016 academic year and who have successfully completed six lab application classes. A total of 46 pre-service teachers participated into the study. In accordance with phenomenology pattern, individuals who experience the focus of the study and who can reflect this were determined as data source (Creswell, 2008). Demographic characteristics of pre-service teachers are given in Table 1.

Table 1. Demographic Characteristics of Pre-Service Physics Teachers

\begin{tabular}{ccc}
\hline Class Level & Frequency (f) & Percentage (\%) \\
\hline 2 & 11 & 23,91 \\
3 & 10 & 21,73 \\
4 & 13 & 28,26 \\
5 & 12 & 26,08 \\
\hline
\end{tabular}

When Table 1 is examined, it can be seen that $11(23,91 \%)$ of the pre-service teachers who participated in the study having successfully completed the lab course are sophomores, 10 of them $(21,73 \%)$ are juniors, 13 of them $(28,26 \%)$ are seniors, and 12 of them $(26,08 \%)$ are fifth year students. In the study, pre-service teachers were 
determined according to criteria sampling method, which is one of the purposeful sampling methods. Purposeful sampling makes it possible to scrutinize certain situations that are determined within the scope of a study (Patton, 1997). Criterion sampling, on the other hand, aims to examine through concrete data the aim of the study and the individuals who meet the previously determined criteria of the study (Yıldırım \& Şimşek, 2013). In this respect, criteria was determined by the researchers; the criteria is that pre-service teachers should participate at least two physics lab applications beforehand, they should successfully complete them, and they should be realizing these applications in the future (Erişti \& Akbulut, 2014). Considering the criteria, applications with pre-service teachers were carried out at the end of the semester. Consequently, the study was run with the participation of pre-service physics teachers enrolled at a faculty of education.

\section{Data Collection}

Data of the study was gathered by the "Physics Lab Application Metaphors Form" that was designed by the researchers. The form consists of two parts. In the first part, pre-service teachers were asked what class level they belong to. In the second part, pre-service teachers were asked to answers such semi-constructed questions as "For me physics lab applications are like..... because ..." Pre-service teachers were asked to put a metaphor about physics lab applications to the first blank and an explanation about that metaphor in the second blank. They were asked specifically to provide an explanation and fill in that blank accordingly because each metaphor can be loaded with different meanings. As such, the researchers will be able to ascertain to what purpose their metaphors are used (Yıldırım \& Şimşek, 2013). The forms hand-scribed by the pre-service teachers were evaluated as "documents," and these documents constitute the basic data source of the study. In addition to these, expert opinions of three people, who hold a PhD in the field of physics education, were consulted in the development phase of the form; the form got its final shape after the corrections and rearrangements according to the views of the experts. Before the application, pre-service teachers were informed about metaphors, and the application was completed in 15 minutes. Moreover, because the aim in this study is to reveal pre-service teachers' perceptions concerning lab applications through metaphors, interviews were held with pre-service teachers in order to support the data obtained in the study and to express them in a more expressive way. Pre-service teachers were determined by taking into consideration the metaphoric perceptions that are in the conceptual category which was formed as a result of the analysis of metaphors. Within this context, interviews were held with nine pre-service teachers, preservice teachers were selected making sure there are at least two people in each category. In the interviews preservice teachers were asked to explain why they mentioned the metaphors they have mentioned, and they were asked to explain the reasons again.

\section{Data Analysis}

Analysis and interpretation of data were realized by content analysis. Data had to be gathered under categories and themes in order to explain pre-service teachers' perceptions concerning lab applications through metaphors. Thus, content analysis was utilized in accordance with the aim of the study. In order to explain the obtained data with content analysis, concepts and relations were reached first and conceptual categories and themes were determined in order to examine more thoroughly the data which were summarized in descriptive analysis (Yildirım \& Şimşek, 2013). Data obtained in the study were expressed in a descriptive narrative, and direct quotations from pre-service teachers were frequently given. Consequently, data obtained from the pre-service teachers' application of "Physics Lab Application Metaphors Form" were transferred to electronic media. It was determined that expressions support the metaphor. After this, a total of 46 people participated in the study, and no data loss happened. The relationship between metaphors and categories was frequently supported by direct quotations. As a result, within the context of content analysis, data resembling each other were gathered under certain conceptual categories and themes, and they were interpreted by being arranged in a way that makes sense to the reader (Yıldırım \& Şimşek, 2013). To this end, metaphors of pre-service teachers were also analyzed according to Saban (2009). In the analysis, during the coding and sorting phase, metaphors were coded and whether pre-service teachers' explanations of metaphors are complete. In the classification phase, similar explanations were gathered under same categories. In the development of categories phase, categories were given names under themes. Names given to categories were determined in accordance with the explanations. The reason categories were gathered under one theme is that explanations and metaphors emphasize learning by doing and experiencing. In the validity and reliability phase, metaphors were compared in terms of theme, category, classification, and codes by three experts with PhDs who have already been involved in metaphor studies before, and these experts made an analysis of the first three phases. For the metaphors that they had disagreements, experts came together again and made the classification of these metaphors under a certain category and theme after a common evaluation. Moreover, 
agreement and disagreement between experts and researchers were determined in order to calculate the reliability of the study. By applying the formula suggested by Miles and Huberman (1994) [Reliability= Agreement/ (Agreement + Disagreement) x 100], the reliability of the study was calculated to be $90 \%$. In qualitative studies, according to Miles and Huberman (1994), if the agreement between experts and researchers is $90 \%$ or higher, the study is accepted to be reliable. In this case, it can be said that reliability and validity of the study was obtained through these means. Finally, during the phase of transfer of data to computer environment, metaphors formed by pre-service teachers were transferred to electronic media.

\section{Findings}

In the study, perceptions of 46 pre-service teachers concerning "Physics lab application" were tried to be determined. It was determined that pre-service teachers generated 10 different metaphors on physics lab application. These metaphors were gathered under seven conceptual categories by the researchers. These seven conceptual categories were handled under one theme. Metaphors generated by pre-service teachers, conceptual categories in which these metaphors are included, and the theme can be seen in Table 2.

Table 2. Distribution of Metaphors on Physics Lab Application According to Conceptual Categories and the Theme

\begin{tabular}{|c|c|c|c|c|c|c|}
\hline \multirow[b]{2}{*}{ Theme } & \multirow[b]{2}{*}{$\begin{array}{l}\text { Conceptual } \\
\text { Categories }\end{array}$} & \multirow[b]{2}{*}{$(\mathbf{f}, \%)$} & \multicolumn{4}{|c|}{ Class levels $(\mathrm{f}, \%)(\mathrm{N}=46)$} \\
\hline & & & $\begin{array}{c}\text { Metaphors of } \\
2^{\text {nd }} \text { year pre- } \\
\text { service } \\
\text { teachers } \\
(f, \%)(N=11)\end{array}$ & $\begin{array}{c}\text { Metaphors of } \\
3^{\text {rd }} \text { year pre- } \\
\text { service } \\
\text { teachers } \\
(f, \%)(N=10)\end{array}$ & $\begin{array}{c}\text { Metaphors of } \\
4^{\text {th }} \text { year pre- } \\
\text { service } \\
\text { teachers } \\
(f, \%)(N=13)\end{array}$ & $\begin{array}{c}\text { Metaphors of } \\
5^{\text {th }} \text { year pre- } \\
\text { service } \\
\text { teachers } \\
(f, \%)(N=12)\end{array}$ \\
\hline \multirow{7}{*}{ 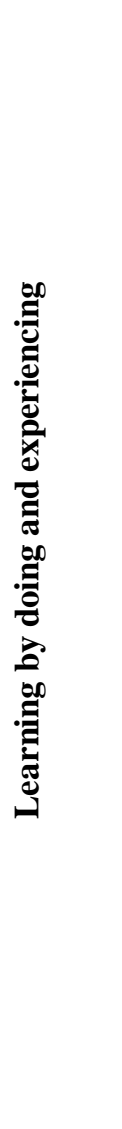 } & $\begin{array}{l}\text { Learning by } \\
\text { having fun }\end{array}$ & $\begin{array}{c}8 \\
(17,39 \%)\end{array}$ & $\begin{array}{l}\text { Playing at a } \\
\text { theme park } \\
(2,18,18 \%)\end{array}$ & - & $\begin{array}{c}\text { Playing an } \\
\text { educative } \\
\text { game } \\
(2,15,38 \%)\end{array}$ & $\begin{array}{l}\text { Playing at a } \\
\text { theme park } \\
(4,33,33 \%)\end{array}$ \\
\hline & $\begin{array}{c}\text { Learning by } \\
\text { labor }\end{array}$ & $\begin{array}{c}9 \\
(19,56 \%)\end{array}$ & $\begin{array}{r}\text { Cooking } \\
(2,18,18 \%)\end{array}$ & $\begin{array}{l}\text { Cooking } \\
(4,40 \%)\end{array}$ & $\begin{array}{r}\text { Cooking } \\
(3,23,07 \%)\end{array}$ & - \\
\hline & $\begin{array}{c}\text { Learning by } \\
\text { trying }\end{array}$ & $\begin{array}{c}5 \\
(10,86 \%)\end{array}$ & $\begin{array}{c}\text { Shaping a play } \\
\text { dough } \\
(2,18,18 \%)\end{array}$ & - & - & $\begin{array}{c}\text { Life } \\
(3,25 \%)\end{array}$ \\
\hline & $\begin{array}{c}\text { Learning by } \\
\text { visual impact }\end{array}$ & $\begin{array}{c}17 \\
(36,95 \%)\end{array}$ & $\begin{array}{c}\text { Working at an } \\
\text { atelier } \\
(5,45,45 \%)\end{array}$ & $\begin{array}{c}\text { Working at an } \\
\text { atelier } \\
(3,30 \%)\end{array}$ & $\begin{array}{c}\text { Working at an } \\
\text { atelier }\end{array}$ & $\begin{array}{c}\text { Working at an } \\
\text { atelier }\end{array}$ \\
\hline & $\begin{array}{c}\text { Learning by } \\
\text { developing }\end{array}$ & $\begin{array}{c}3 \\
(6,52 \%)\end{array}$ & - & $\begin{array}{l}\text { Having } \\
\text { graduate } \\
\text { studies } \\
(1,10 \%)\end{array}$ & $\begin{array}{c}\text { Working of a } \\
\text { factory }\end{array}$ & - \\
\hline & $\begin{array}{l}\text { Learning by } \\
\text { being curious }\end{array}$ & $\begin{array}{c}2 \\
(4,34 \%)\end{array}$ & - & $\begin{array}{c}\text { Watching a } \\
\text { documentary } \\
(2,20 \%)\end{array}$ & - & - \\
\hline & $\begin{array}{c}\text { Learning by } \\
\text { getting } \\
\text { directions }\end{array}$ & $\begin{array}{c}2 \\
(4,34 \%)\end{array}$ & - & - & $\begin{array}{l}\text { Using the GPS } \\
(2,15,38 \%)\end{array}$ & - \\
\hline
\end{tabular}


Metaphors generated by the pre-service teachers were categorized according to their commonalities by the researchers, and seven different conceptual categories were obtained. These seven different categories were handled under the "learning/experiencing by doing" theme. Names given to categories were determined in accordance with explanations. The reason categories were gathered under one theme is that explanations and metaphors emphasize learning by doing and experiencing. Conceptual categories and the theme were determined by the researchers through mutual agreement. As can be seen in Table 2, it was determined that "working in an atelier" is the most frequently expressed metaphor being used by $17(36,95 \%)$ pre-service teachers. It is followed by "cooking" used by $9(19,56 \%)$ pre-service teachers, and "playing in the theme park" used by $6(13,04 \%)$ preservice teachers. Following these are "Life" (6,52\%), "Playing an educative game" (4,34\%), "Shaping play dough" $(4,34 \%)$, "Using navigation" (4,34\%), and "having a graduate study" $(2,17 \%)$. It was seen that the most frequently used metaphor is under the conceptual category of learning through visual impact $(36,95 \%)$. This conceptual category is followed by these conceptual categories: learning by labor $(19,56 \%)$, learning by having fun $(6,52 \%)$, learning by being curious $(4,34 \%)$, and learning by getting directions $(4,34 \%)$. Conceptual categories under the learning by doing/experiencing theme, metaphors under these categories, and the reasons for these metaphors are given in detail below.

Under the "learning by visual impact" conceptual category is working at an atelier metaphor. Pre-service teachers think that a visual learning takes place with physics lab application. Expressions of pre-service teachers are given below (*: Class Level, PT: Pre-service physics teacher, \#: Coding number):

2PT3: For me, physics lab application is like working in an atelier, because it becomes more fun when you know how data work and how data can be structured. I think we learn better in physics labs by touching and seeing.

4PT5: For me, physics lab application is like working in an atelier, because just like labs, ateliers are effective environments for us to turn theoretical knowledge into permanent by visual impact, and they are effective in forming meaningful learning.

The conceptual category titled "learning by labor" consists of cooking metaphor. It can be said that pre-service teachers think physics lab application require labor. Their views are given below:

2PT8: For me, physics lab application is like cooking, because your ingredients is the formulae, you have the recipe, and you put it into action, and your labors give you wonderful results.

3PT10: for me, physics lab application is like cooking because, just as you enjoy it more when you cook yourself and as it takes better because you cook it as you like it, your learning is more permanent as you do experiments in the laboratory. Therefore, when we see that we are able to understand and work on a certain topic on our own, we get more pleasure.

The conceptual category "Learning by having fun" includes such metaphors as playing in a theme park and playing an educative game. Pre-service teachers indicated that physics lab application is a form of learning by having fun. Their views are given below:

5PT3: For me, physics lab application is like playing in a theme park, because we can create a world of our own in the theme park with toys. In laboratories, too, we can make some inventions by thinking of experiments as games instead of being very rigid.

4PT1: For me, physics lab application is like playing an educative game, because students have fun and their learning is permanent as lab applications provide learning by having fun.

In the conceptual category "Learning by improving" includes such metaphors as having a graduate study and the working of a factory. Pre-service teachers emphasized that learning takes place through showing improvement during the process in lab applications. Here are some of their views:

3PT2: For me, physics lab application is like having graduate studies because normally we build on our previous knowledge in classes. Laboratories are beneficial as they enable us to reflect on what we have learned and they improve us.

4PT8: For me, physics lab application is like the working of a factory, because in factories, first you have arrangements based on data and then you reach results after going through certain processes. In laboratories, too, you choose an experiment that is appropriate for the aim of the topic, and you go through several phases and then you have improvement, and then you have meaningful learning. 
In the conceptual category "learning by trial" includes such metaphors as shaping a play dough and life. Preservice teachers contend that one reaches the result by trying, and that is how learning takes place. Views of preservice teachers are given below:

2PT11: For me, physics lab application is like shaping play dough, because it enables us to learn by doing and trying. It teaches us to get better results by trying harder and to never give up and keep trying.

5PT5: For me, physics lab application is like life, because just as in life, in lab applications you learn by trying.

In the conceptual category "learning by being curious" includes the metaphor "watching a documentary." Preservice teachers indicated that learning takes place in lab applications through curiosity. Here are their views:

3PT4: For me, physics lab application is like watching a documentary, because it is an interesting, educative, and curiosity-arousing application.

In the conceptual category "Learning by getting directions includes the metaphor "using the Global Positioning System (GPS)." It was determined that pre-service teachers thought that learning takes place if students are properly directed during the application. Their views are given below:

4PT9: For me, physics lab application is like using the GPS, because when you need improvement, it makes knowledge become permanent through giving proper directions.

In the study, when the metaphors generated by pre-service physics teachers were examined according to their class level, it can be seen that $2^{\text {nd }}$ year students $(45,45 \%), 4^{\text {th }}$ year students $(30,76 \%)$, and $5^{\text {th }}$ year students $(41,66 \%)$ emphasize the conceptual category of learning through visual impact. It was determined that $3^{\text {rd }}$ year students $(40 \%)$ put the category of learning through labor before learning through visual impact. The conceptual category of learning by labor was supported by $3^{\text {rd }}$ year students $(40 \%), 4^{\text {th }}$ year students $(23,07 \%)$, and $2^{\text {nd }}$ year students $(18,18 \%)$, respectively from the most frequent to the least; however, $5^{\text {th }}$ year students have not given any expressions in this category. It was determined that $5^{\text {th }}$ year pre-service teachers are the ones who contribute to the category of learning by having fun $(33,33 \%)$, and they are followed by $4^{\text {th }}$ year students $(15,38 \%)$, and $2^{\text {nd }}$ year students $(18,18 \%)$. It was also seen that $3^{\text {rd }}$ year students have not generated any metaphors in this category.

It was determined that there are expressions only from $5^{\text {th }}(25 \%)$ and $2^{\text {nd }}$ year students $(18,18 \%)$ in the learning by trial category. It was also determined that learning by development was supported most frequently by the $4^{\text {th }}$ year pre-service teachers $(15,38 \%)$, and they were followed by $3^{\text {rd }}$ year pre-service teachers $(10 \%)$. Moreover, $2^{\text {nd }}$ and $5^{\text {th }}$ year pre-service teachers had not generated any metaphors for this category. Finally, learning by being curious was indicated only by $3^{\text {rd }}$ year pre-service teachers $(20 \%)$ and learning by getting directions was indicated only by $4^{\text {th }}$ year pre-service teachers $(15,38 \%)$.

Finally, because the aim of the study was to reveal pre-service teachers' perceptions concerning lab applications through metaphors, interviews were held with pre-service teachers in order to support the data obtained in the study and to express them in a more expressive way. Within this context, interviews were held with nine preservice teachers, pre-service teachers were selected making sure there are at least two people in each category. In the interviews pre-service teachers were asked to explain why they mentioned the metaphors they have mentioned, and they were asked to explain the reasons again. As a result of the interviews, it was determined that pre-service teachers supported the expressions they wrote on the forms, and that they tried to explain their metaphors in their own words. Pre-service teachers' expressions are given below:

"I can always learn something new by trying in physics labs. I love labs. They complement my theoretical knowledge. I can also make observations there. Labs make it possible for me to turn my abstract knowledge into concrete. Thus, I think of physics lab as shaping play dough. By using the dough in our hand, by experimenting with it, we can shape it and make it meaningful. Thus, I can concretize my theoretical knowledge through selfexperience."

"I love labs. I can make observations while experimenting, and these observations come to me when I solve questions, and they guide me. In fact, labs are like cooking. It demands labor, it makes you work for it. Then, when we put the ingredients together, a product comes into being. In labs, too, are such phases as going step by step, labor, combining information in a particular order, and bringing out a product." 
"Because physics is everywhere, I find labs very entertaining as they are the application fields of physics. I resemble physics labs to playing in a theme park. Just as in a theme park, I have fun and I learn. Moreover, this knowledge becomes permanent."

"I think and reflect on the topic more when I am in the lab experimenting than when I am in class, because I am curious about in what order I put together which theoretical knowledge that I have. In the labs, I get the chance to put into practice what we have learned in class, and I satisfy my curiosity. I can find answers to my questions. In fact, I liken labs to watching documentaries. I learn by being curious when I watch documentaries as well. I have a more meaningful learning as I get answers to what I am curious about. Moreover, details are permanently put together due to visualization."

"Thanks to labs, I can concretize my theoretical abstract knowledge. I think of physics lab as working in an atelier. We get the chance experience what we have in mind and we can get concrete data. Just like atelier workers, who make production through turning theoretical into practice, we also visualize our theoretical knowledge with applications; we can get a product, and thus ensure permanent learning through visualization."

"I love labs because they enliven classes. In my opinion, labs are like playing an educative game because we can learn while playing. We have some knowledge, but we usually do not know in which order we should put things. Then we put this knowledge in proper use; we have fun and we learn at the same time."

"Labs are like cooking, in my opinion. First you need to go to the bazaar, and buy the necessary ingredients. Then, we put our knowledge into use by using their ingredients. Lab classes require labor. As a result, I think labs are the kitchens of physics classes, because the core of a job is learned in the kitchen, and there is no result without labor. We put the ingredients together following a recipe, and thus we ensure meaningful learning through our own labor."

"Labs are among my favorite classes. I have so much fun during labs. I learn as much as I have fun. Thus, they are beneficial. I liken physics lab to playing in a theme park. I have such fun in theme parks and I think about how those machines in the theme park work. In physics lab, I learned the working principle of fast trains and the Ferris wheel. I can say I now know about the things I like. In short, I have as much fun in physics lab as I do in a theme park, and I learn many conceptual things while having fun."

"I love physics lab and I think it guides me. I can make up my shortage of knowledge thanks to lab classes. In fact, labs are like using the GPS, because they guide me and make it possible for me to reach the end through an applied and correct way, and in the end a meaningful learning is achieved. I like how lab experiments guide me. Thus, I can reach the end through the shortest and the most correct way."

\section{Discussion, Conclusion and Suggestions}

In the study, the aim was to determine pre-service physics teachers' perceptions concerning "Physics lab application" through metaphors. In the study, it was determined that 46 pre-service physics teachers generated 10 metaphors concerning physics lab application. These metaphors were gathered under seven conceptual categories by the researchers within the thematic frame of learning by doing and experiencing. Perception towards physics lab application was determined through the frequently used metaphors of pre-service teachers, such as "working at an atelier," "cooking," and "playing at a theme park." In addition to these metaphors, such metaphors as "life," "playing an educative game," "shaping a play dough," "workings of a factory," "watching a documentary," "using the GPS," and "having graduate studies" were also determined to be expressed by the pre-service teachers. It was seen that the majority of the metaphors expressed by pre-service teachers are under the conceptual category of learning through visual impact. This conceptual category was followed by the conceptual categories of learning by labor, learning by having fun, learning by trial, learning by developing, learning by being curious, and learning by getting directions.

When literature is examined, in a study conducted by Çifçili and Kırbaşlar (2015) on general physics lab, it was determined that pre-service teachers expressed life as a metaphor in the meaningful learning category, and toy shop and playground as metaphors in the learning by having fun category. It was claimed that, as was the case in this study, labs enabled learning by trial. In the study, along with the life metaphor within the learning by trial conceptual category, there was shaping play dough, which has not been found in literature. Pre-service teachers emphasized with this metaphor, just like with the life metaphor, that they learn in a more meaningful way by doing and experiencing. Gunstone and Champagne (1990) indicated that if pre-service teachers are given enough time, 
there will be meaningful learning in lab applications due to interactions and trial and errors. Moreover, it can be claimed that experiments are thought of as games by the pre-service teachers as they constantly associated physics lab with playing in a theme park, playing an educative game in the study, and with playground in literature; it can also be claimed that learning takes place through learning by having fun. It is thought that physics lab applications make learning permanent and meaningful, and at the same time pre-service teachers develop a positive viewpoint towards the class as they take an active role in lab applications (Domin, 1999; Hofstein, 2004). In a study realized by Hofstein and Lunetta (1982), it was determined that pre-service teachers enjoy lab applications as they think of them as game, and that lab applications are influential in pre-service teachers' attitudes towards the course. In this context, it can be argued that Hofstein and Lunetta's (1982) study supports this study. It is known that working at an atelier metaphor falls under the conceptual category of learning through visual impact. In literature, it was indicated that lab applications have a positive contribution to the concretization and better comprehension of theoretical knowledge acquired in classes (Hofstein \& Naaman, 2007). Here, it was underlined that learning through visual impact plays an important role in learning concepts, and the result of the study was supported. At the same time, in Şahin-Pekmez' (2001) study, it was indicated that pre-service teachers learn a topic better when they were enabled to explore knowledge on their own and when their problem solving skills as well as hand skills are improved. It can be argued that this expression overlaps with the cooking metaphor, because pre-service teachers uttered that a better learning can take place through learning by labor, that is to say, by using their manual skills on their own. In addition to all these, it is expressed in literature that learning approaches in labs are among the factors affecting learning. With the learning approach to be assumed in lab applications, it is expected that preservice teachers will be curious and that they will question and research the knowledge they have acquired. As was indicated in the study, watching a documentary metaphor puts forth the fact that lab applications are curiosityarousing, interesting, and educative. Findings obtained in the study actually show that physics lab applications are helpful for pre-service teachers in learning by being curious (Hofstein et al., 2004). In the study, having graduate studies and workings of a factory, which are metaphors under the conceptual category of learning through development indicate that meaningful learning takes place when one proceeds following steps in lab applications. A study by Feyzioğlu et al (2011) supports this finding; it indicates that a more permanent learning takes place when relations are drawn between concepts through a long process, and thus effectiveness can be increased as such. Finally, with the using the GPS metaphor in the conceptual category of learning by getting directions, preservice teachers indicated that getting directions make permanent the knowledge they want to learn or to complete. In literature, it was indicated that applications that take place with the experiment leaflets and the lecturer are more interesting for the student and that this contribute to their success and development of their skills (Açışl1, 2004). In short, it was argued that meaningful learning can take place when physics lab applications are done with the guidance of lecturers and experiment leaflets. Under the light of all these findings, it is clear that objectives in physics education cannot be attained without lab applications.

Another finding of the study is that pre-service teachers generate positive metaphors for physics lab applications, but the conceptual categories and the frequency of expressions vary according to class level. The fact that pre-service teachers generated positive metaphors makes one think that labs are realized appropriately during the university education. In addition, when pre-service physics teachers' metaphors concerning physics lab applications were examined according to class level, it can be seen that the majority of pre-service teachers expressed the conceptual category of learning through visual impact. Following this are the conceptual categories of learning by labor and learning by having fun. The fact that pre-service teachers have generated metaphors frequently in these conceptual categories show that they have fun during lab applications, they learn by doing and experiencing, and they can concretize abstract concepts. The fact that these categories are followed by the conceptual categories of learning by trial and learning by developing makes one think that they could make sense of theoretical knowledge in a process by trial and by drawing relations. Pre-service teachers put the conceptual categories of learning by being curious and learning by getting directions. In this context, it is revealed that preservice teachers think that physics lab applications increase curiosity and that learning can be realized with the guidance of a guide. Looking at the conceptual categories expressed by pre-service teachers, it is thought that physics lab applications are beneficial for the professional development of pre-service teachers.

In conclusion, the importance of developing pre-service teachers' skills of research based on observation and experiment is well-known. It can be said that effective and meaningful learning is realized with the active participation of pre-service teachers as a result of physics lab applications, because these labs enable learning by doing and experiencing. At the same time, labs aim to make pre-service teachers more equipped in terms of 
knowledge and skills. In this process, it can be suggested that pre-service teachers should be helped on their way to improvement (Sar1, 2013). In addition to this, it is thought that appropriate and equipped environments should be forms where pre-service teachers can have physics lab applications in order to make them learn concepts of physics, reveal their sense of curiosity, increase their motivation, and enable them to learn by experiencing, touching, and observing (Güneş et al., 2013). 


\section{Öğretmen Adaylarının Fizik Laboratuvar Uygulamasına İlişkin Metaforik Algılarının İncelenmesi}

Giriş

Bilim ve teknolojinin hızla gelişmesi ile günümüzde ülkelerin bilimsel ve teknolojik anlamda sürekli gelişim göstermesi beklenmektedir. Bu geliş̧im düzeyi eğitim ile değişsenlik gösterebilmektedir. Eğitim nitelikli insan gücünün gelişmesini, bireylerin düşünme becerilerinin, bilgilerinin ve anlayışlarının geliştirilmesini sağlamaktadır (Collette ve Chiapetta, 1989). Aynı zamanda kaliteli bir eğitim anlayışılyla bilim ve teknolojideki gelişmelere uyum sağlamaya aracı olacak bireylerin yetiștirilmesi hedeflenmektedir (Yalım, 2002). Bu doğrultuda bireylere bilgiye ulaşma, kavrayarak öğrenme, yaparak yaşayarak öğrenme, öğrenme sürecine aktif katılım becerileri özellikle fen bilimleri öğretimi ile sağlanabilmektedir (Sarı, 2013). Fen bilimleri insanın doğuşundan günümüze kadar ihtiyaçları gidermek amacıyla var olan bilimsel bilgileri içermektedir (Çilenti, 1985). Fen bilimleri ile teknolojide gelişmeler sağlanarak toplumun gelişmesi amaçlanmaktadır. Fen öğretimi ile gelecekte söz sahibi olacak gelişmiş bir ülkenin bireylerinin ve teknolojik gelişmeleri algılayarak yorumlayabilen fen bilimleri eğitimi almış bireylerin yetiştirilmesi planlanmaktadır. Fen öğretiminde bilim ve teknolojik gelişimlere uygun bireylerin yetiştirilmesinde laboratuvarın önemli bir rol oynadığı bilinmektedir (Çepni, Ayas, Johnson ve Turgut, 1997). Çünkü laboratuvarlar bilgilerin yaparak ve yaşayarak öğrenilmesini sağlamaktadır. Laboratuvarlar aslında eğitimin vazgeçilmezleri arasında bulunmaktadır. Laboratuvar ortamı öğrencilerin konulara aktif katılım, günlük yaşamla konuyu ilişkilendirebilme ve bilgiyi yapılandırabilme firsatı sunmaktadır (Tatar, Korkmaz ve Şaşmaz Ören, 2007). Kısacası laboratuvarlar fen öğretimi içerisinde büyük önem arz etmektedir (Yenice, 2005). Fen öğretimi içerisinde yer alan konu ve kavramlar doğası gereği bir çok disiplini kapsamaktadır. Bu disiplinler fizik, kimya ve biyoloji olarak ayrılmaktadır. Fen öğretimi içerisinde yer alan disiplinlerde öğrencilerin kavram ve yasalara yaşayarak deneysel uygulamalar ile ulaşması ve anlamlı öğrenmenin gerçekleştirilmesi aynı şekilde önem arz etmektedir. $\mathrm{Bu}$ nedenle araştırmada ele alınan fizik öğretiminde de laboratuvarların etkili bir faktör olduğu söylenebilir (Lawson, 1995). Fizik öğretiminde laboratuvar uygulamaları aracılığıyla kalıcı ve anlamlı öğrenme sağlanabilmekte ve grup çalışmalarına firsat verilebilmektedir (Kesercioğlu ve Aydoğdu, 2005). Laboratuvarlarda teorik bilgilerin pratiğe dönüştürülmesi, deneyim kazanılması ve el becerisinin gelişimi sağlanmaktadır (Ayas, 2006). Tüm bu noktalardan yola çıkıldığında laboratuvarın fen eğitiminin ve fizik öğretiminin ayrılmaz bir parçası olduğu ortaya çıkmaktadır. Ayrıca fizik derslerinin anlaşılabilmesi ve fizik öğretiminin etkili ve kalıcı olabilmesi için laboratuvar uygulamalarından yararlanılmasının şart olduğu düşünülmektedir (Sarı, 2013). Alanyazında laboratuvar uygulamalarının öğretimde önemli olduğu ve kullanılması gerektiği, ancak etkili bir şekilde de kullanılamadığı yer almaktadır (Alpaut, 1993; Ekici, 1996). Laboratuvar uygulamalarına yönelik olumsuz görüşlerin genellikle laboratuvarlarla ilgili yeterli bilgi ve beceriye ulaşılamaması ve uygulamalarda sıkıntı çekilmesi olduğu belirtilmektedir (Çallıca ve diğerleri, 2001). Bu bakımdan ülkemizde laboratuvar uygulamalarının amacına uygun etkili bir şekilde yapılabilmesinde öğretmen adayları önemli rol oynamaktadır. Öğretmen adaylarının mevcut probleme çözüm getirebilecekleri ve bunun gelecek nesillere taşınabileceği düşünülmektedir. $\mathrm{Bu}$ kapsam araştırmada da fizik öğretmen adaylarının fizik laboratuvar uygulamasına yönelik algılarının ortaya çıkarılmasıyla laboratuvar uygulamaların değerlendirilmesi ve bu değerlendirmenin de bilgi kaynağı olarak alana yarar sağlaması amaçlanmaktadır. Fizik öğretmen adaylarının algılarının ortaya çıkarılmasında ise metaforlardan yararlanılmıştır. Metaforlar olayların anlaş̧labildiği, açıklanabildiği bir dilsel araç olarak ifade edilmektedir. Metaforlar aracılığıyla insanların algıları ortaya çıkarılabilmektedir (Arnett, 1999). Gerçekler bireyler tarafindan tekrar tanımlanarak kavramsallaştırılmaktadır (Goldstein, 2005). Bu sayede metaforlar analiz edilmesi istenen kavramın nasıl algılandığının belirlemesine katkı sağlamaktadır (Cerit, 2008). Öğretmen adaylarının öğrenim gördükleri anabilim dalında mekanik, elektrik ve manyetizma, elektronik, titreşim ve dalgalar, optik ve modern fizik olmak üzere altı adet fizik laboratuvar dersleri bulunmaktadır. Araştırmada fizik laboratuvar uygulamaları olarak bahsedilen ifade ile fizik laboratuvar dersleri kastedilmektedir. Sonuç olarak bu altı uygulama dersi araştırmacılar tarafindan fizik laboratuvar uygulamaları başlı̆̆ altında tanımlanmıştır. Böylece araştırmada fizik öğretmen adaylarının "Fizik laboratuvar uygulaması" ile ilgili metaforlarının belirlenerek, adayların fizik laboratuvarına yönelik algılarının ortaya çıkarılması istenmektedir.

\section{Araştırmanın Amacı ve Önemi}

Fizik öğretiminde etkili ve kalıcı öğrenme, ezberleyerek öğrenme yerine kavramların anlamlandırılarak öğrenilmesi ile gerçekleştirilebilmektedir. Anlamlı öğrenme önceki bilgilerin yeni öğrenilen bilgilerle ilişkilendirilmesi ve yeniden yapılandırılması olarak ifade edilebilir. Fizik öğretiminde etkili, kalıcı ve anlamlı öğrenme ile öğrencilerin süreç içerisinde aktif olduğu, başarılarının arttığı bir öğretim hedeflenmektedir. Bu 
doğrultuda laboratuvar uygulamalarının teorik bilgilerin deneyler ile anlamlandırılarak öğrenilmesini sağladığ düşünüldüğünde, bu uygulamanın bilgilerin kalıcılığı sağladığı ve fizik öğretiminde önem arz ettiği ortaya çıkmaktadır. Fizik dersi içerisinde yer alan kavramların genellikle anlaşılmasında zorluk çekildiği, formüllere dayalı bir ders olarak görüldüğü bilinmektedir. Öğrencilerin kavramları zihinlerinde oluşturmada zorluk çektikleri ve bu zorlukların da kavram yanılgılarına sebep olduğu araştırmalarla belirlenmiştir (Halloun, 1997). Buna yönelik laboratuvar uygulamaları ile kavramların öğrencilere keşfettirilmesi ve olayların resmedilmesi amaçlanmaktadır (Bozkurt ve Sarıkoç, 2008). Laboratuvar uygulamalarının öğretmen adaylarının akademik başarı ve tutumlarını arttığının bilinmesinin yanında, problem çözme, bilişsel süreç ve eleştirel düşünme becerileri üzerinde etkili olduğu söylenebilir (Akben, 2011; Hodson, 1988; Hofstein, Navon, Kipnis ve Mamlok, 2005). Ayn1 zamanda laboratuvar uygulamaları aracılığıyla araştıran ve sorgulayan öğretmen adaylarının yetiştirildiğine inanılmaktadır. Alanyazında laboratuvar uygulamalarının fen eğitiminin merkezinde yer aldığ sağlanacak öğretimin yararlı olduğu vurgulanmaktadır (Pickering, 1980; Hofstein ve Lunetta, 2003; Tobin, 1990). Laboratuvar çalışmaları alanyazında kavramsal ve etkili öğrenme gerçekleştirmede, teknik ve araştırma becerisi kazandırmada alana yarar sağladığı şeklinde ele alınmıştır (Boud ve diğerleri, 1986; Garnet ve O'Loughlin, 1989; Woolnough, 1991; Garnett, Garnett ve Hackling, 1995). Laboratuvar uygulamalarının öneminin gerçekleştirilen araştırmalarda belirtilmesi ile, laboratuvar uygulamaları kullanılarak bilimsel bilgilere nasıl ulaşabileceğini bilen öğrencilerin gelişiminde eğitim fakültelerinin önemli bir rol oynadığı söylenebilir. Eğitim fakültelerinde yetişen öğretmen adaylarının laboratuvar uygulamalarına yönelik algıları bu noktada önem kazanmaktadır. İyi bir fizik eğitiminin temelini laboratuvar uygulamalarının teşkil ettiği düşünüldüğünde (Yener, 2010), araştırmada gelecekte laboratuvar uygulamalarının uygulayıcısı olacak fizik öğretmen adaylarının fizik laboratuvar uygulamalarına yönelik algılarının metaforlar aracılığıyla belirlenmesi amaçlanmıştır. Araştırmada elde edilecek bulguların alana katkı sağlayacağı düşünülmektedir. Bu doğrultuda araştırmada aşağıdaki sorulara yanıt aranmıştır:

1. Fizik öğretmen adayları fizik laboratuvar uygulamasına yönelik hangi metaforları üretmişlerdir?

2. Fizik öğretmen adaylarının fizik laboratuvar uygulamasına yönelik sahip oldukları metaforlar ortak özellikler bakımından hangi kavramsal kategoriler altında toplanabilir?

3. Fizik öğretmen adaylarının fizik laboratuvar uygulamasına yönelik geliştirdikleri metaforlar öğretmen adaylarının öğrenim gördüğü sınıf seviyesine göre farklılaşmakta mıdır?

\section{Yöntem}

\section{Araştırma Deseni}

Araştırmada fizik öğretmen adaylarının "Fizik laboratuvar uygulaması” kavramına ilişkin metaforik algılarının incelenebilmesi amacıyla nitel araştırma yöntemleri içerisinde yer alan olgu bilim deseninden yararlanılmıştır. Olgu bilim deseni aracılığıyla her bir bireyin kendi deneyimleri ile oluşturduğu yaşam dünyasına, düşüncelerine ve algılarına ulaşılması sağlanabilmektedir (Christensen, Johnson ve Turner, 2011). Aynı zamanda olgu bilim bireylerin deneyimlerini nasıl anlamlandırdıklarının ve bunu zihinlerine nasıl aktardıklarının, tasnif ettiklerinin, değerlendirdiklerinin ortaya çıkarılmasına imkan sağlamaktadır (Patton, 2014). Olgu bilim, farkında olunan ancak derinlemesine ve ayrıntılı bir anlayışa sahip olmadığımız kavramlara odaklanılmasını sağlayanda bir desendir (Creswell, 2003). Bu bakımından araştırmanın doğasına uygun olduğu düşünülen olgu bilim deseninden araştırmada yararlanılmıştır.

\section{Çalışma Grubu}

Araştırmanın çalışma grubunu 2015-2016 eğitim ve öğretim yılında Ankara'da bulunan bir devlet üniversitesinin eğitim fakültesinin fizik öğretmenliği bölümünde öğrenim görmekte ve altı adet laboratuvar uygulama dersini alarak başarılı bir şekilde tamamlamış olan öğretmen adayları oluşturmaktadır. Araştırma toplamda 46 öğretmen adayının katılımı ile gerçekleştirilmiştir. Olgu bilim desenine de uygun olarak, araştırmanın odaklandığı konuyu yaşayan ve bu durumu yansıtabilecek bireyler veri kaynağı olarak belirlenmiştir (Creswell, 2008). Öğretmen adaylarının demografik özellikleri Tablo 1'de yer almaktadır. 
Tablo 1. Fizik Öğretmen Adaylarının Demografik Özellikleri

\begin{tabular}{ccc}
\hline Sinıf Düzeyi & Frekans (f) & Yüzde (\%) \\
\hline 2 & 11 & 23,91 \\
3 & 10 & 21,73 \\
4 & 13 & 28,26 \\
5 & 12 & 26,08 \\
\hline
\end{tabular}

Tablo 1 incelendiğinde araştırmaya katılan ve laboratuvar dersi alarak başarı ile tamamlamış olan fizik öğretmen adaylarının $11(\% 23,91)$ 'inin 2. sınıf, $10(21,73)$ 'unun 3. sinıf, $13(\% 28,26)$ 'ünün 4 . sınıf ve 12 (\%26,08)'sinin 5. sınıf olduğu görülmektedir. Araştırmada öğretmen adayları amaçlı örnekleme yöntemleri arasında yer alan ölçüt örnekleme yöntemine uygun olarak belirlenmiş̧ir. Amaçlı örnekleme, araştırma kapsamında belirlenen durumların derinlemesine incelenmesine olanak vermektedir (Patton, 1997). Ölçüt örnekleme ise, önceden belirlenmiş ölçütleri sağlayan bireyler ile araştırmanın amacının somut verilerle irdelenmesini amaçlamaktadır (Yıldırım ve Şimşek, 2013). Bu kapsamda araştırmada ölçüt araştırmacılar tarafindan belirlenmiştir ve ölçütün araştırmaya katılan öğretmen adaylarının en az iki fizik laboratuvar uygulamalarına katılım göstermiş, başarı ile tamamlamış ve gelecekte bu uygulamaları gerçekleştirecek olmaları olarak belirlenmesine karar verilmiştir (Erişti ve Akbulut, 2014). Öğretmen adayları ile gerçekleştirilen uygulamalar ölçüt göz önüne alındığından eğitim ve öğretim döneminin sonunda gerçekleştirilmiştir. Sonuç olarak, araştırma eğitim fakültesinde öğrenim gören fizik öğretmen adayları ile yürütülmüş̧ür.

\section{Verilerin Toplanması}

Araştırmanın verileri araştırmacılar tarafindan hazırlanan "Fizik Laboratuvar Uygulaması Metaforlar Formu" aracılığıyla toplanmıştır. Form iki bölümden oluşmaktadır. İlk bölümde öğretmen adaylarının öğrenim gördüğü sınıf seviyesi sorulmuştur. İkinci bölümde ise "Benim için fizik laboratuvar uygulamas1 ............ gibidir; çünkü, ...." şeklinde yarı yapılandırılmış soru öğretmen adaylarına yöneltilmiştir. Öğretmen adaylarından yarı yapılandırılmış soru içerisindeki ilk boşluğa fizik laboratuvar uygulaması ile ilgili bir metafor yazmaları ve ikinci boşluğa da bu metaforu neden yazdıklarını açıklamaları istenmiştir. Araştırmada açıklama bölümünün özellikle doldurulmasının istenmesi, her bir metafora farklı anlamların yüklenebilecek olmasıdır. Böylece "çünkü" ifadesinin ardından metaforların hangi amaçla kullanıldığı anlaşılmış olacaktır (Yıldırım ve Şimşek, 2013). Öğretmen adayları tarafindan el yazısıyla doldurulan formlar "doküman" olarak değerlendirilmiştir ve araştırmanın temel veri kaynağı olarak nitelendirilmektedir. Bunların yanı sıra, formun geliştirilme sürecinde fizik eğitimi alanında doktora derecesine sahip olan üç uzmandan görüş alınmıştır ve düzenlemeler ile form son halini alarak uygulanmasına karar verilmiştir. Uygulama öncesinde öğretmen adayları metaforlar ile ilgili bilgilendirilmiştir ve uygulama süresi olarak 15 dakika öğretmen adaylarına verilerek uygulama gerçekleştirilmiştir. Ayrıca araştırmada öğretmen adaylarının laboratuvar uygulamalarına yönelik algılarının metaforlarla ortaya çıkarılması amaçlandığından, elde edilen bulguları desteklemek ve daha açıklayıcı bir şekilde ifade edebilmek için öğretmen adayları ile görüşmeler yapılmıştır. Bu öğretmen adayları metaforların analizi sonucunda oluşturulan kavramsal kategoride yer alan metaforik algılar göz önüne alınarak belirlenmiştir. Bu kapsamda dokuz öğretmen adayı ile görüşme yapılmış olup, öğretmen adayları her bir kategoriden en az iki kişi olacak şekilde seçilmiş̧ir. Görüşmelerde öğretmen adaylarından belirtmiş oldukları metaforları neden belirttikleri ve nedenleri ile tekrardan açıklamaları istenmiştir.

\section{Verilerin Analizi}

Araştırmada verilerin çözümlenmesi ve yorumlanması içerik analizi ile gerçekleştirilmiştir. Araştırmada öğretmen adaylarının laboratuvar uygulamalarına yönelik algılarını metaforlar aracılığıyla açıklayabilmek için elde edilen verilerin kategori ve temalar altında toplanması gerekmiştir. Bu nedenle araştırmanın amacına uygun olarak içerik analizinden yararlanılmıştır. İçerik analizi ile öncelikle elde edilen verileri açıklayabilecek için kavramlara ve ilişkilere ulaşılmış ve betimsel analizde özetlenen verilerin daha derinlemesine incelenmesini ifade edebilmek için araştırmada kavramsal kategoriler ve temalar belirlenmiştir (Yıldırım ve Şimşek, 2013). Araştırmada elde edilen veriler betimsel bir anlatımla ifade edilmiştir ve öğretmen adaylarının doğrudan 44 
alıntılarına sık sık yer verilmiştir. Sonuç olarak öncelikle öğretmen adaylarından "Fizik Laboratuvar Uygulaması Metaforlar Formu" uygulaması sonucunda elde edilen veriler elektronik ortama aktarılmıştır. Açıklamaların metaforu desteklediği ifadeler belirlenmiştir. Bu işlem sonrasında toplamda 46 kişi araştırmaya katılmış ve veri kaybı gerçekleşmemiştir. Metaforlar ile kategoriler arasındaki ilişki doğrudan alıntılar ile sık sık desteklenmiştir. Sonuç olarak içerik analizi kapsamında, birbirine benzeyen veriler belirli kavramsal kategoriler ve tema altında bir araya getirilmiştir ve okuyucuların anlayabileceği bir şekilde düzenlenerek yorumlanmıştır (Yıldırım ve Şimşek, 2013). Bu doğrultuda öğretmen adaylarının metaforları Saban (2009)'a göre de analiz edilmiştir. Analizde ilk olarak kodlama ve ayıklama aşamasında; metaforlar kodlanmış ve öğretmen adaylarının tam bir şekilde metaforlarının açıklamalarının tam olup olmadığına bakılmıştır. Sınıflama aşamasında; yapılan açıklamalar dikkate alınarak benzer açıklamalar aynı kategoriler altında toplanmıştır. Kategorileri geliştirme aşamasında; kategoriler tema altında isimlendirilmiştir. Kategorilere verilen isimler açıklamalar doğrultusunda belirlenmiştir. Kategorilerin araştırmada tek bir tema altında toplanmasının nedeni ise, açıklamalar ve metaforların yaparak ve yaşayarak öğrenmeye vurgu yapmasından kaynaklanmaktadır. Geçerlik ve Güvenirlik aşaması; oluşturulan metaforlar daha önce metafor çalışmasına katılmış ve doktora derecesine sahip üç kişi tarafından, ilk üç aşamanın analizi yapılarak tema, kategori, sınıflama ve kodların karşılaştırması ile gerçekleştirilmiştir. Görüş ayrılığı olan metaforlar üzerinde uzmanlar tekrar bir araya gelerek ortak bir değerlendirme ile belirli kategori, tema altında o metaforların sınıflandırılmasını yapmıştır. Ayrıca uzmanlar ve araştırmacılar arasındaki görüş birliği ve görüş ayrılığı tespit edilerek araştırmanın güvenirliği hesaplanmıştır. Miles ve Huberman (1994)'ın önerdiği formül [Güvenirlik = Görüş Birliği/ (Görüş Birliği + Görüş Ayrılığı) x 100] uygulanarak araştırmanın güvenirliği \%90 olarak hesaplanmıştır. Nitel araştırmalarda Miles ve Huberman (1994)'a göre uzmanlar ve araştırmacılar arasındaki görüş birliği \% $\% 0$ ve üzeri oluyorsa, araştırmanın güvenilir olduğu kabul edilmektedir. Bu durumda araştırmanın geçerliği ve güvenilirliği ifade edilen yöntemlerle sağlanmış olduğu söylenebilir. Son olarak verilerin bilgisayar ortamına aktarılması aşamasında; öğretmen adaylarının oluşturmuş olduğu metaforların elektronik ortama aktarılması gerçekleştirilmiştir.

\section{Bulgular}

Araştırmada, 46 fizik öğretmen adayının "Fizik laboratuvar uygulamasına" yönelik algıları belirlenmeye çalışılmıştır. Öğretmen adaylarının fizik laboratuvar uygulaması ile ilgili 10 farklı metafor ürettikleri belirlenmiştir. $\mathrm{Bu}$ metaforlar araştırmacılar tarafından yedi kavramsal kategori altında toplanmıştır. Yedi kavramsal kategori ise, bir tema altında ele alınmıştır. Öğretmen adayları tarafından üretilen metaforlar, metaforların içerisinde yer aldığı kavramsal kategoriler ve tema Tablo 2'de yer almaktadır.

Tablo 2. Fizik Laboratuvar Uygulamasına Yönelik Metaforların Kavramsal Kategorilere ve Temaya Göre Dağılımı

\begin{tabular}{|c|c|c|c|c|c|c|}
\hline \multirow[b]{2}{*}{ Tema } & \multirow[b]{2}{*}{$\begin{array}{l}\text { Kavramsal } \\
\text { Kategoriler }\end{array}$} & \multirow[b]{2}{*}{$(f, \%)$} & \multicolumn{4}{|c|}{ Sınıf Düzeyleri (f,\%) $(\mathrm{N}=46)$} \\
\hline & & & $\begin{array}{c}\text { 2. sınıf } \\
\text { öğretmen } \\
\text { adaylarının } \\
\text { metaforları } \\
(\mathbf{f}, \%)(\mathrm{N}=11)\end{array}$ & $\begin{array}{c}\text { 3. Sınıf } \\
\text { ögretmen } \\
\text { adaylarının } \\
\text { metaforları } \\
(\mathbf{f}, \%)(\mathrm{N}=10)\end{array}$ & $\begin{array}{c}\text { 4. sınıf } \\
\text { öğretmen } \\
\text { adaylarının } \\
\text { metaforları } \\
(\mathbf{f}, \%)(\mathrm{N}=13)\end{array}$ & $\begin{array}{c}\text { 5. sınıf } \\
\text { ögrretmen } \\
\text { adaylarının } \\
\text { metaforları } \\
(\mathbf{f}, \%)(\mathrm{N}=12)\end{array}$ \\
\hline \multirow{3}{*}{ 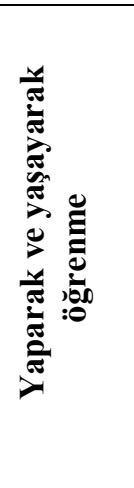 } & $\begin{array}{c}\text { Eğlenerek } \\
\text { öğrenme }\end{array}$ & $\begin{array}{c}8 \\
(\% 17,39)\end{array}$ & $\begin{array}{c}\text { Lunaparkta } \\
\text { oyun oynamak } \\
(2, \% 18,18)\end{array}$ & - & $\begin{array}{c}\text { Eğitici bir } \\
\text { oyun oynamak } \\
(2, \% 15,38)\end{array}$ & $\begin{array}{c}\text { Lunaparkta } \\
\text { oyun oynamak } \\
(4, \% 33,33)\end{array}$ \\
\hline & $\begin{array}{c}\text { Emek vererek } \\
\text { öğrenme }\end{array}$ & $\begin{array}{c}9 \\
(\% 19,56)\end{array}$ & $\begin{array}{c}\text { Yemek } \\
\text { yapmak } \\
(2, \% 18,18)\end{array}$ & $\begin{array}{c}\text { Yemek } \\
\text { yapmak } \\
(4, \% 40)\end{array}$ & $\begin{array}{c}\text { Yemek } \\
\text { yapmak } \\
(3, \% 23,07)\end{array}$ & - \\
\hline & $\begin{array}{c}\text { Deneyerek } \\
\text { öğrenme }\end{array}$ & $\begin{array}{c}5 \\
(\% 10,86)\end{array}$ & $\begin{array}{c}\text { Oyun } \\
\text { hamuruna } \\
\text { şekil vermek } \\
(2, \% 18,18)\end{array}$ & - & - & $\begin{array}{l}\text { Hayat } \\
(3, \% 25)\end{array}$ \\
\hline
\end{tabular}




\begin{tabular}{|c|c|c|c|c|c|}
\hline $\begin{array}{c}\text { Görsel etkiyle } \\
\text { öğrenme }\end{array}$ & $\begin{array}{c}17 \\
(\% 36,95)\end{array}$ & $\begin{array}{c}\text { Atölyede } \\
\text { çalışmak } \\
(5, \% 45,45)\end{array}$ & $\begin{array}{l}\text { Atölyede } \\
\text { çalışmak } \\
(3, \% 30)\end{array}$ & $\begin{array}{c}\text { Atölyede } \\
\text { çalışmak } \\
(4, \% 30,76)\end{array}$ & $\begin{array}{c}\text { Atölyede } \\
\text { çalışmak } \\
(5, \% 41,66)\end{array}$ \\
\hline $\begin{array}{c}\text { Gelişim } \\
\text { sağlayarak } \\
\text { öğrenme }\end{array}$ & $\begin{array}{c}3 \\
(\% 6,52)\end{array}$ & - & $\begin{array}{l}\text { Lisansüstü } \\
\text { öğrenim } \\
\text { görmek } \\
(1, \% 10)\end{array}$ & $\begin{array}{c}\text { Fabrikadaki } \\
\text { işleyiş } \\
(2, \% 15,38)\end{array}$ & - \\
\hline $\begin{array}{c}\text { Merak } \\
\text { duygusuyla } \\
\text { öğrenme }\end{array}$ & $\begin{array}{c}2 \\
(\% 4,34)\end{array}$ & - & $\begin{array}{l}\text { Belgesel } \\
\text { izlemek } \\
(2, \% 20)\end{array}$ & - & - \\
\hline $\begin{array}{l}\text { Yönlendirilerek } \\
\text { öğrenme }\end{array}$ & $\begin{array}{c}2 \\
(\% 4,34)\end{array}$ & - & - & $\begin{array}{c}\text { Navigasyon } \\
\text { kullanmak } \\
(2, \% 15,38)\end{array}$ & - \\
\hline
\end{tabular}

Öğretmen adaylarının oluşturduğu metaforlar araştırmacılar tarafından ortak özellikleri bakımından kategorize edilmiştir ve yedi farklı kavramsal kategori elde edilmiştir. Bu yedi farklı kategoride yaparak ve yaşayarak öğrenme teması altında ele alınmıştır. Kategorilere verilen isimler açıklamalar doğrultusunda belirlenmiştir. Kategorilerin araştırmada tek bir tema altında toplanmasının nedeni ise, açıklamalar ve metaforların yaparak ve yaşayarak öğrenmeye vurgu yapmasından kaynaklanmaktadır. Kavramsal kategoriler ve tema araştırmacılar tarafindan ortak kabul görerek belirlenmiştir ve üzerinde uzlaşma sağlanmıştır. Tablo 2'de görüldüğü üzere 17 $(\% 36,95)$ öğretmen adayı tarafindan en fazla ifade edilen metaforun 'Atölyede çalışmak' olduğu tespit edilmiştir. Bu metaforu $9(\% 19,56)$ öğretmen adayı ifadesi ile 'Yemek yapmak' ve $6(\% 13,04)$ öğretmen adayı ifadesi ile 'Lunaparkta oyun oynamak' takip etmektedir. Bu metaforların ardına 'Hayat' (\%6,52), 'Eğitici bir oyun oynamak' $(\% 4,34)$, 'Oyun hamuruna şekil vermek' $(\% 4,34)$, 'Fabrikadaki işleyiş̧ $(\% 4,34)$, 'Belgesel izlemek' $(\% 4,34)$, 'Navigasyon kullanmak' $(\% 4,34)$ ve 'Lisansüstü öğrenim görmek' $(\% 2,17)$ metaforları gelmektedir. En fazla ifade edilen metaforun ise görsel etkiyle öğrenme $(\% 36,95)$ kavramsal kategorisi altında yer aldığı görülmektedir. Bu kavramsal kategorinin ardından emek vererek öğrenme $(\% 19,56)$, eğlenerek öğrenme $(\% 17,39)$, deneyerek öğrenme $(\% 10,86)$, gelişim sağlayarak öğrenme $(\% 6,52)$, merak duygusuyla öğrenme $(\% 4,34)$ ve yönlendirilerek öğrenme $(\% 4,34)$ kavramsal kategorileri gelmektedir. Yaparak ve yaşayarak öğrenme teması altında bulunan kavramsal kategorilere, kavramsal kategoriler altındaki metaforlara ve metaforların gerekçelerine aşağıda ayrıntılı bir şekilde yer verilmiştir.

"Görsel etkiyle öğrenme" kavramsal kategorisi altında atölyede çalışmak metaforu yer almaktadır. Öğretmen adayları fizik laboratuvar uygulaması ile görsel olarak öğrenmenin gerçekleştiğini düşünmektedirler. Öğretmen adaylarının ifadeleri aşağıda yer almaktadır ( ${ }^{*}$ : Sınıf Düzeyi, ÖA: Fizik öğretmen adayı, \#: Kodlama numarası):

2ÖA3: Benim için fizik laboratuvar uygulaması atölyede çalışmak gibidir; çünkü verilerin nasıı çalıştığı ve nasıl yapılandırılabileceği bilindiğinde konu daha zevkli hale gelir. Bence fizik laboratuvarında dokunarak görerek daha iyi öğreniyoruz.

4ÖA5: Benim için fizik laboratuvar uygulaması atölyede çalışmak gibidir; çünkü atölyelerde laboratuvarlar gibi öncesinde öğrendiğimiz teorik bilgileri görsel etkiyle kalıcı hale getirme yeri ve anlamlı öğrenmenin oluşmasında etkili bir ortamdır.

"Emek vererek öğrenme" kavramsal kategorisi ise yemek yapmak metaforunu kapsamaktadır. Öğretmen adaylarının fizik laboratuvar uygulamasına emek harcanması gerektiğini düşündükleri söylenebilir. Öğretmen adayı görüşleri aşağıda bulunmaktadır:

2ÖA8: Benim için fizik laboratuvar uygulaması yemek yapmak gibidir; çünkü malzemeler formüllerin, bilgilerin yerindedir, sen onu uygulamaya koyarsın ve emeklerin ile muhteşem sonuçlara ulaşırsın. 
3ÖA10: Benim için fizik laboratuvar uygulaması yemek yapmak gibidir; çünkü nasıl kendi yemeğimizi kendimiz yaptığımızda daha çok keyif alarak ve isteğimize uygun pişirdiğimiz için daha lezzetli oluyorsa, laboratuvarda da kendimiz emek harcayarak ve bilgilerimizi kullanarak deneyleri yaptığımız için öğrenilen bilgiler daha kalıcı bilgi oluyor. Bu sayede konuyu daha iyi anlayıp, konudan zevk alarak yapabildiğimizi görünce konudan daha çok haz duyuyoruz.

"Eğlenerek öğrenme" kavramsal kategorisi lunaparkta oyun oynamak ve eğitici bir oyun oynamak metaforlarını içermektedir. Fizik laboratuvar uygulamasının eğlenerek öğrenme şekli olduğu öğretmen adayları tarafından belirtilmiştir. Adayların ifadelerine aşağıda yer verilmiştir:

5ÖA3: Benim için fizik laboratuvar uygulaması lunaparkta oyun oynamak gibidir; çünkü lunaparkta istediğimiz oyuncaklarla istediğimiz bir dünya yaratabiliyoruz. Laboratuvarlarda da deneyi belli amaç ve yöntemlere göre yapmak yerine deneyleri oyun gibi düşünerek eğlenerek bazı buluşlar yapabiliyoruz.

4ÖA1: Benim için fizik laboratuvar uygulaması eğitici bir oyun oynamak gibidir; çünkü laboratuvar uygulamalarında eğlenerek öğrenme gerçekleştiğinden öğrencilere bilgilerin öğrenilmesi hem zevkli gelmekte hem de öğrenilenler hafizada kalıcı olmaktadır.

"Gelişim sağlayarak öğrenme" kavramsal kategorisi altında lisansüstü öğrenim görmek ve fabrikadaki işleyiş metaforları yer almaktadır. Öğretmen adayları laboratuvar uygulamalarında süreç içerisinde gelişim göstererek öğrenmenin gerçekleştiğini düşündüklerini vurgulamışlardır. Adayların görüşleri aşağıda bulunmaktadır:

3ÖA2: Benim için fizik laboratuvar uygulaması lisansüstü öğrenim görmek gibidir; çünkü normalde derslerde öğrendiğimizin üstüne koyarız. Laboratuvarlarda uzun bir süreçte öğrendiklerimizin üstüne düşündürücü ve geliştirici düzeyde yarar sağlanmaktadır.

4ÖA8: Benim için fizik laboratuvar uygulaması fabrikadaki işleyiş gibidir; çünkü fabrikada önce veriler üzerinde düzenlemeler yapılır ve belirli aşamalardan geçilerek uzun sürede gelişim gösteren verilerin sonucuna ulaşılır. Laboratuvarda da öncesinde anlatılan konunun amacına uygun deney seçilir ve aşamalar doğrultusunda ilerlendiğinde gelişim sağlayarak anlamlı öğrenme gerçekleşir.

"Deneyerek öğrenme" kavramsal kategorisi oyun hamuruna şekil vermek ve hayat metaforlarını içermektedir. Adaylar laboratuvar uygulamalarında deneyerek sonuca ulaşıldığını ve bu şekilde öğrenmenin gerçekleştiğini savunmaktadırlar. Öğretmen adaylarının görüşlerine aşağıda yer verilmiştir:

2ÖA11: Benim için fizik laboratuvar uygulaması oyun hamuruna şekil vermek gibidir; çünkü yaparak ve deneyerek öğrenmemizi sağlar. Uğraştıkça daha güzel sonuçlar almamızı ve bıkmadan denemeyi öğretir.

5ÖA5: Benim için fizik laboratuvar uygulaması hayat gibidir; çünkü laboratuvar uygulamalarında hayatta olduğu gibi deneyerek öğrenme gerçekleşir.

"Merak duygusuyla öğrenme" kavramsal kategorisi altında belgesel izlemek metaforu yer almaktadır. Öğretmen adaylarının laboratuvar uygulamasında merak duygusu ile öğrenme gerçekleştiğini düşündükleri belirlenmiş̧ir. Adayların görüşleri aşă̆ıdadır:

3ÖA4: Benim için fizik laboratuvar uygulaması belgesel izlemek gibidir; çünkü merak uyandırıcı, ilgi çekici, öğretici bir uygulamadır.

"Yönlendirilerek öğrenme" kavramsal kategorisi navigasyon kullanmak metaforunu kapsamaktadır. Adayların uygulamada yönlendirildikleri taktirde öğrenmenin gerçekleşebildiğini düşündükleri saptanmıştır. Öğretmen adayların ifadeleri aşă̆ıda yer almaktadır:

4ÖA9: Benim için fizik laboratuvar uygulaması navigasyon kullanmak gibidir; çünkü eksik olduğun ya da daha iyi öğrenmek istediğin bilginin yönlendirilme ile kalıcı hale gelmesi sağlanır.

Araştırmada fizik öğretmen adaylarının fizik laboratuvar uygulaması kavramına yönelik geliştirdikleri metaforlar öğretmen adaylarının öğrenim gördüğü sınıf seviyesine göre incelendiğinde, 2. (\%45,45), 4. (\%30,76) ve 5. $(\% 41,66)$ sınıf öğretmen adaylarının görsel etkiyle öğrenme kavramsal kategorisine ağırlık verdikleri dikkat çekmektedir. 3. sınıf öğretmen adaylarının ise emek vererek öğrenme (\%40) kategorisini, görsel etkiyle öğrenme (\%30) kategorisinin önüne koydukları belirlenmiştir. Emek vererek öğrenme kavramsal kategorisini çoktan aza doğru sırasıyla 3. $(\% 40), 4$. $(\% 23,07)$ ve $2 .(\% 18,18)$ sınıf ögretmen adayları desteklemiştir, ancak 5. sinıftaki adayları bu kategoriye yönelik ifade de bulunmamışlardır. Eğlenerek öğrenme kategorisine ise en çok 5. $(\% 33,33)$ 
sınıfların katılım gösterdiği, ardından da 4. $(\% 15,38)$ ve 2. $(\% 18,18)$ sınıf adaylarının geldiği tespit edilmiştir. 3. sınıf adayların bu kavramsal kategoriye yönelik metafor üretmedikleri görülmektedir. Deneyerek öğrenme kavramsal kategorisini sadece 5. $(\% 25)$ ve 2. $(\% 18,18)$ sınıf öğretmen adaylarının ifade ettikleri tespit edilmiştir. Gelişim sağlayarak öğrenmenin gerçekleşmesi kategorisini ise 4. $(\% 15,38)$ sınıf öğretmen adayları en fazla desteklerken, onları bu kategoride 3. (\%10) sinıftaki adaylar takip etmektedir. Ayrıca 2. ve 5. sinıftaki adaylar bu kategoriye yönelik metafor üretmemişlerdir. Son olarak merak duygusuyla öğrenmeyi sadece 3. (\%20) ve yönlendirilerek öğrenmeyi de 4. $(\% 15,38)$ sınıf öğretmen adayları belirtmişlerdir.

Son olarak araştırmada öğretmen adaylarının laboratuvar uygulamalarına yönelik algılarının metaforlarla ortaya çıkarılması amaçlandığından, elde edilen bulguları desteklemek ve daha açıklayıcı bir şekilde ifade edebilmek için öğretmen adayları ile görüşmeler yapılmıştır. Bu kapsamda dokuz öğretmen adayı ile görüşme yapılmış olup, öğretmen adayları her bir kategoriden en az iki kişi olacak şekilde seçilmiştir. Görüşmelerde öğretmen adaylarından belirtmiş oldukları metaforları neden belirttikleri ve nedenleri ile tekrardan açıklamaları istenmiştir. Görüşmeler sonucunda adayların formda yazdıkları ifadeleri desteklediği ve metaforlarını tekrar kendi ifadeleri ile açıklamaya çalıştıkları tespit edilmiştir. Öğretmen adayı ifadeleri aşağıda yer almaktadır:

“Fizik laboratuvarında sürekli yeni bir şeyler deneyerek öğrenebiliyorum. Laboratuvarları seviyorum. Teorik bilgimi destekliyor. Aynı zamanda orada gözlem yapabiliyorum. Laboratuvarlar soyut bilgilerimi somutlaştırmamı sağlıyor. Bu nedenle fizik laboratuvarını bir oyun hamuruna şekil vermek gibi düşünüyorum. Elimizdeki hamurları kullanarak, deneyerek onlara şekil veriyoruz ve onları anlamlı bir şekilde birleştiriyoruz. Böylece teorik bilgilerimi kendim deneyerek somutlaştırabiliyorum."

"Laboratuvarı çok seviyorum. Laboratuvarlarda deneyleri yaparken gözlemliyorum ve bu yaptığım gözlemler soru çözerken aklıma geliyor, bana yol gösterici oluyor. Aslında fizik laboratuvarlart yemek yapmak gibidir. Öncelikle emek istiyor, seni uğraştırlyor. Daha sonra malzemeleri özveri ile ortaya koyduğumuzda ürünümüz ortaya çıkıyor. Laboratuvarlarda da adım adım ilerleme, emek, bilgileri sırasıyla birleştirme ve ürünü ortaya çıkarma basamakları yer almaktadır.”

"Her şeyin içinde fizik olduğu için fiziğin uygulama alanı olan laboratuvarları çok ĕ̆lenceli buluyorum. Fizik laboratuvarlarını lunaparkta oyun oynamaya benzetiyorum. Lunaparklarda olduğu gibi hem eğleniyorum hem ögreniyorum. Aynı zamanda ögretici olan bu bilgiler bende kalıcı hale geliyor."

"Laboratuvarlarda deney yaparken ben derslerden daha çok düşünüyorum. Çünkü ögrrendiğim teorik bilgilerimin hangilerinin hangi sirayla bir araya getirdiğimde ne olacağını merak ediyorum. Laboratuvarlarda derste verilen bilgileri uygulamaya koyma ve merakım giderme şansım oluyor. Soru işaretlerime cevap bulabiliyorum. Aslında laboratuvarları belgesel izlemekle bağdaştırtyorum. Ben belgesel izlerken de merak ederek öğreniyorum. Merak ettiklerime yanıt bulmamla daha anlamlı ögreniyorum. Aynı zamanda görsellikle kafamdaki ayrintılar kalıcı olarak birleşiyor."

"Laboratuvarlar sayesinde teorik öğrendiğim soyut bilgileri somutlaştırabiliyorum. Fizik laboratuvarını atölyede çalışmak gibi düşünüyorum. Aklımızdaki fikirleri deneyimleme şanımız oluyor ve somut veriler elde edebiliyoruz. Atölye çalışanları gibi teorik olan şeyleri uygulamaya dökerek üretim yapıyorlar. Bizde teorik bilgilerimizi uygulamalarla görselleştiriyoruz, ürün elde edebiliyoruz ve böylece görsellikle kalıcı öğrenme sağlayabiliyoruz."

"Laboratuvart seviyorum çünkü laboratuvarlar dersleri renklendiriyor. Bana göre laboratuvarlar eğitici bir oyun oynamak gibidir. Çünkü eğlenirken öğrenebiliyoruz. Bilgi birikimimiz var ama neyi nereye hangi sirayla koyacağımızı tam bilmiyoruz ama sonra bu bilgileri uygun bir şekilde boşluklara yerleştirerek hem eğleniyoruz hem de ögreniyoruz."

"Laboratuvarlar bana göre yemek yapmak gibidir. Illk önce pazara gitmek gerekiyor gerekli malzemeleri almak gerekiyor. Daha sonra bu malzemeleri kullanarak bilgilerimizi birleştirebiliyoruz. Laboratuvar dersleri öncesinde ve işlem sırasında emek istemektedir. Sonuç olarak fizik derslerinin mutfağının laboratuvarlar olduğunu düşünüyorum. Çünkü iş asıl mutfă̆ında ögrenilir, emek olmadan da sonuç olamaz. Malzemeleri doğru bir şekilde tarifine uygun birleştiriyoruz ve bu şekilde kendi emeğimizle anlamlı öğrenme sağlanmış oluyoruz."

"Laboratuvar dersi en sevdiğim dersler arasında yer alıyor. Ben laboratuvar derslerinde çok ĕgleniyorum. Ĕ̆lendiğim kadar da aslında öğreniyorum. Bu nedenle bana faydalı oluyor. Fizik laboratuvarını ben lunaparkta oyun oynamaya benzetiyorum. Lunaparkta ben çok eğlenirim ve oradaki aletlerin çalışma prensibini hep 48 
düşünürüm. Fizik laboratuvarında hızlı trenin ve dönme dolabın çallşma prensiplerini öğrendim, artık eğlendiğim aletlerle ilgili sahibiyim de diyebilirim. Kısacast fizik laboratuvarında lunaparkta oyun oynamak kadar eğleniyorum ve aynı zamanda birçok kavramsal bilgiyi eğlenirken ögreniyorum."

"Fizik laboratuvarın seviyorum ve bana yol gösterici olduğunu düşünüyorum. Eksik bilgilerimi laboratuvar dersleri sayesinde tamamlayabiliyorum. Fizik laboratuvarı aslında navigasyon kullanmak gibidir. Çünkü bana yol gösteriyor sonuca doğru bir şekilde uygulamal ve anlamlı öğrenme gerçekleştirerek ulaşmamı sağllyor. Laboratuvardaki deneylerin beni yönlendirmesini seviyorum. Böylece sonuca en kisa ve doğru yoldan ulaşabiliyorum."

\section{Tartışma, Sonuç ve Öneriler}

Araştırmada fizik öğretmenliği adaylarının "Fizik laboratuvar uygulaması" kavramına yönelik algılarının metaforlar aracılığıyla belirlenmesi amaçlanmıştır. Araştırmada, 46 fizik öğretmen adayının fizik laboratuvar uygulaması ile ilgili 10 metafor ürettikleri belirlenmiştir. Bu metaforlar araştırmacılar tarafindan yaparak ve yaşayarak öğrenme teması kapsamında yedi kavramsal kategori altında toplanmıştır. Öğretmen adaylarının sıklıkla kullandıkları 'Atölyede çalışmak', 'Yemek yapmak' ve 'Lunaparkta oyun oynamak' metaforları ile fizik laboratuvar uygulamasına yönelik algılar belirlenmiştir. Bu metaforların yanında adaylar 'Hayat', 'Eğitici bir oyun oynamak', 'Oyun hamuruna şekil vermek', 'Fabrikadaki işleyiş', 'Belgesel izlemek', 'Navigasyon kullanmak' ve 'Lisansüstü öğrenim görmek' gibi kavramları da ifade ettikleri tespit edilmiştir. Öğretmen adayları tarafindan ifade edilen metaforların çoğunluğunun görsel etkiyle öğrenme kavramsal kategorisi altında yer aldığı saptanmıştır. Bu kavramsal kategoriyi emek vererek öğrenme, eğlenerek öğrenme, deneyerek öğrenme, gelişim sağlayarak öğrenme, merak duygusuyla öğrenme ve yönlendirilerek öğrenme kavramsal kategorileri takip etmektedir.

Alan yazın incelendiğinde Çifçili ve Kırbaşlar (2015) tarafından gerçekleştirilen çalışmada, genel fizik laboratuvarına yönelik öğretmen adaylarının anlamlı öğrenme kategorisi içerisinde hayat metaforuna, eğlenerek öğrenmede kategorisinde de oyuncak dükkanı, oyun alanı metaforlarına yer verdiği belirlenmiştir. Araştırmada olduğu gibi hayat metaforu ile laboratuvarlarda deneyerek öğrenmenin gerçekleştiği savunulmaktadır. Araştırmada deneyerek öğrenme kavramsal kategorisi altında hayat metaforu ile birlikte bulunan, ancak alanyazında yer almayan oyun hamuruna şekil vermek metaforuna rastlanılmıştır. Öğretmen adayları bu metafor ile hayat metaforunda olduğu gibi kendilerinin uğraşarak, deneyerek ve yaparak bilgiyi daha anlamlı öğrendiklerini vurgulamaktadırlar. Gunstone ve Champagne (1990), öğretmen adaylarına yeterli süre verildiği takdirde laboratuvar uygulamalarında etkileşimler ve yansımalar sonucu anlamlı öğrenme olduğunu ifade etmişlerdir. Ayrıca fizik laboratuvarının araştırmada lunaparkta oyun oynamak, eğitici bir oyun oynamak ve alanyazında oyun alanı metaforu ile bağdaştırılması sonucu, deneylerin öğretmen adayları tarafından aslında oyun gibi düşünüldüğü ve bu şekilde eğlenerek öğrenmelerinin gerçekleştiği söylenebilir. Fizik laboratuvar uygulamalarının öğrenmeyi anlamlı ve kalıcı kıldığı, aynı zamanda öğretmen adaylarının laboratuvar uygulamalarında aktif rol alarak derse karşı olumlu bir bakış açısı geliştirdikleri düşünülmektedir (Domin, 1999; Hofstein, 2004). Hofstein ve Lunetta (1982) tarafindan gerçekleştirilen araştırmada, laboratuvar uygulamalarından oyun gibi düşünülerek zevk alındığı ve öğretmen adaylarının derse karşı tutumlarında laboratuvar uygulamalarının etkili olduğu tespit edilmiş̧ir. Bu kapsamda Hofstein ve Lunetta (1982)'nın araştırmasının, bu araştırmayı destekler nitelikte olduğu söylenebilir. Atölyede çalışmak metaforunun araştırmada görsel etkiyle öğrenme kavramsal kategorisi içine girdiği bilinmektedir. Alanyazında teorik derslerde öğrenilen kuramsal bilgilerin ve soyut kavramların somutlaştırılmasında ve daha anlaşılır hale gelmesinde laboratuvar uygulamalarının etkililiğinin söz konusu olduğu belirtilmektedir (Hofstein ve Naaman, 2007). Burada görsel etkiyle öğrenmenin kavramların öğreniminde önemli rol oynadığ 1 dile getirilmekte ve araştırmanın sonucu desteklenmektedir. Aynı zamanda öğretmen adaylarının bilgiyi kendi kendilerine keşfetmeleri, problem çözme yeteneklerinin ve el becerilerinin geliştirilmesinin sağlanması ile konuları daha iyi öğrenebildikleri Şahin-Pekmez (2001)'in çalışmasında yer almaktadır. Bu ifadenin ise araştırmada yer alan yemek yapmak metaforu ile örtüştüğü söylenebilir. Çünkü araştırmada olduğu gibi öğretmen adayları kendi kendilerine ve el becerilerini kullanarak, yani emek vererek daha iyi öğrenmenin gerçekleşebileceği ifade etmişlerdir. Bunların yanı sıra alanyazında laboratuvardaki öğrenme yaklaşımının da öğrenmeyi etkileyen etmenler arasında yer aldığı belirtilmektedir. Laboratuvar uygulamalarında benimsenecek öğrenme yaklaşımı ile öğretmen adaylarının merak duygusunu ortaya çıkararak bilgiyi sorgulamaları ve araştırmaları beklenmektedir. Araştırmada da ifade edildiği üzere, belgesel izlemek metaforu laboratuvar uygulamalarının merak uyandırıcı, ilgi çekici, öğretici olduğunu ortaya koymaktadır. Araştırmada elde edilen sonuç aslında öğretmen adaylarının merak duygusuyla öğrenmelerine fizik laboratuvar uygulamalarının yardımcı olduğu göstermektedir (Hofstein ve diğerleri, 2004). Araştırmada gelişim sağlayarak kavramsal 
kategorisi altında yer alan lisansüstü öğrenim görmek ve fabrikadaki işleyiş metaforları ise, laboratuvar uygulamalarında aşamalar doğrultusunda ilerlendiğinde anlamlı öğrenmenin gerçekleşebileceğini belirtmektedir. Feyzioğlu ve diğerleri (2011) tarafindan gerçekleştirilen araştırma bu sonucu destekler nitelikte olup, uzun süreçte kavramlar arasındaki ilişki kurularak daha kalıcı öğrenmenin gerçekleşebileceğini ve bu şekilde verimliliğin artabileceğini ifade etmektedirler. Son olarak yönlendirilerek öğrenme kavramsal kategorisinde bulunan navigasyon kullanmak metaforu ile öğretmen adayları eksik oldukları ya da daha iyi öğrenmek istedikleri bilginin yönlendirilme ile kalıcı hale geldiğini belirtmişlerdir. Alanyazında, deney föyleri ve öğretim elemanı eşliğinde gerçekleştirilen uygulamaların öğrencinin daha çok dikkatini çektiği ve bunun öğretmen adaylarının başarılarına, bilimsel süreç becerilerinin gelişimine katkı sağladığı yer almaktadır (Açışlı, 2014). Kısacası, fizik laboratuvar uygulamalarına deney föylerinin ya da öğretim elemanının rehber olması ile anlamlı öğrenmenin gerçekleşebildiği savunulmaktadır. Tüm sonuçlar doğrultusunda ise, fizik eğitiminde laboratuvar uygulamaları olmadan istenilen hedeflere ulaşılamayacağı ortaya çıkmaktadır.

Araştırmada elde edilen diğer bir sonuçta öğretmen adaylarının fizik laboratuvar uygulamalarına yönelik olumlu metafor geliştirdikleri, ancak sınıf düzeylerinde ifade edilen kavramsal kategorilerin ve ifade ediliş sıklığının değiştiğidir. Öğretmen adaylarının olumlu metafor üretmeleri üniversitedeki eğitim ve öğretim sürecinde laboratuvarların amacına uygun gerçekleştirildiğini düşündürmektedir. Bunun yanı sıra fizik öğretmen adaylarının fizik laboratuvar uygulaması kavramına yönelik geliştirdikleri metaforlar öğretmen adaylarının öğrenim gördüğü sınıf seviyesine göre incelendiğinde, öğretmen adaylarının çoğunluğunun görsel etkiyle öğrenme kavramsal kategorisini belirttiği görülmektedir. Bunu takiben emek vererek öğrenme ve eğlenerek öğrenme kavramsal kategorileri gelmektedir. Öğretmen adaylarının sıklıkla bu kavramsal kategorilere yönelik metafor üretmeleri, laboratuvar uygulamalarında eğlendiklerini, yaparak yaşayarak öğrendiklerini ve soyut kavramları görsellikle somutlaştırabildiklerini göstermektedir. Ardından deneyerek öğrenme ve gelişim sağlayarak öğrenme kavramsal kategorilerine yer vermelerinin ise, teorik olarak edinilen bilgilerin süreç içerisinde deneyerek ve ilişkilendirilerek anlamlandırıldığını düşündürmektedir. Son sıraya öğretmen adayları merak duygusuyla öğrenme ve yönlendirilerek öğrenme kavramsal kategorilerini koymuşlardır. $\mathrm{Bu}$ kapsamda da fizik laboratuvar uygulamalarının merak duygusunu arttırdığı ve rehber eşliğinde öğrenimin gerçekleşebileceğinin düşünüldüğünü ortaya çıkmaktadır. Öğretmen adayları tarafından ifade edilen kavramsal kategorilerden yola çıkıldığında, fizik laboratuvar uygulamalarının öğretmen adaylarının mesleki gelişimlerine fayda sağlayacağı düşünülmektedir.

Sonuç olarak, fizik eğitiminde öğretmen adaylarının gözlem ve deneye dayalı olarak araştırma yapma becerisinin geliştirilmesinin önemli olduğu bilinmektedir. Fizik laboratuvar uygulamalarının sonucunda da öğretmen adaylarının aktif katılımı sağlanarak etkili ve kalıcı öğrenmenin gerçekleştiği söylenebilir. Çünkü laboratuvarlar yaparak yaşayarak öğrenmeye imkan sağlamaktadır. Aynı zamanda öğretmen adaylarının bilgi ve beceri açısından daha donanımlı hale gelmeleri laboratuvarlarda amaçlanmaktadır. Bu süreç içerisinde öğretmen adaylarının gelişimlerine yardımcı olunması gerektiği önerilebilir (Sarı, 2013). Bunların yanında özellikle konular içerisinde yer alan fizik kavramlarını öğretmen adaylarına daha iyi kavratabilmek, onlardaki merak duygusunu ortaya çıkarabilmek, motivasyonlarını arttırabilmek ve yaşayarak, dokunarak, gözlemleyerek öğrenmelerin gerçekleşmesi için fizik laboratuvar uygulamalarının gerçekleştirilebileceği uygun ve donanımlı ortamların oluşturması gerektiği düşünülmektedir (Güneş ve diğerleri, 2013). 


\section{References}

Açışlı, S. (2014). Genel fizik laboratuvar uygulamalarında 5e öğrenme modeline göre geliştirilen materyallerin öğrencilerin bilimsel süreç becerilerine ve akademik başarılarına etkisinin incelenmesi [The examination of the effect of the materials developed accordings to the 5e learning model on the students' scientific process skills and academic achievement in general physics laboratory applications]. Ondokuz Mayis University Journal of Faculty of Education, 33(2), 628-641.

Akben, N. (2011). Öğretmen adaylar için bilimsel sorgulama destekli laboratuvar dersi geliştirme [Developing a laboratory-guided laboratory course for prospective teachers]. Unpublished Doctoral Dissertation, Gazi University, Ankara.

Alpaut, O. (1993). Fen eğitiminin verimli ve işlevsel hale getirilmesi [Making science education efficient and functional].Symposium on science education and problems in secondary education institutions, TED, Ankara.

Arnett, R. C. (1999). Metaphorical Guidance: Administration as Building and Renovation. Journal of Educational Administration, 37(1), 80-89.

Ayas, A. (2006). Fen bilgisi ögretiminde laboratuar kullanımı [Use of laboratories in science teaching]. Anadolu University Publications.

Boud, D., Dunn, J., \& Hegarty-Hazel, E. (1986).Teaching in laboratories. Guildford: SRHE \& NFER-Nelson.

Bozkurt, E. \& Sarıkoç, A. (2008). Fizik eğitiminde sanal laboratuar, geleneksel laboratuarın yerini tutabilir mi? [Can the virtual laboratory replace the traditional laboratory in physics education?]. Ahmet Kelesoglu Education Faculty Journal, 25, 89-100.

Cerit, Y. (2008). Öğretmen kavramı ile ilgili metaforlara ilişkin öğrenci, öğretmen ve müdürlerin görüşleri [Students, teachers, and administrators' views on metaphors with respect to the concept of teacher]. The Journal of Turkish Educational Sciences, 4(6), 693-712.

Christensen, B. L., Johnson, R. B., \& Turner L. A. (2011). Research methods, design and analysis. Boston: Pearson.

Collette, E. L., \& Chiapetta, A. (1989). Teaching science in middle and secondary schools. Berril Publishing Company, Toronto.

Creswell, J. W. (2003). Qualitative, quantitative, and mixed methods approaches (2nd ed.). London: Sage.

Creswell, J. W. (2008). Educational research planning, conducting and evaluating quantitative and qualitative research. International Pearson Merril Prentice Hall.

Çallıca, H., Erol, M., Sezgin, G., \& Kavcar, N. (2001). İlköğretim kurumlarında laboratuar uygulamalarına ilişskin bir çallşma [A study on laboratory practices in primary education institutions]. IV. Science Education Symposium, Milli Eğitim Publications, Ankara.

Çepni, S., Ayas, A., Johnson, D., \& Turgut, M. F. (1997). Fizik Öğretimi [Physics Teaching]. Ankara: YÖK/Dünya Bankası National Education Development Project, Pre-Service Teacher Training.

Çif̧̧ili, V., \& Kırbaşlar, G. F. (2015). Investigating perceptions of pre-service teachers towards laboratories by using phenomenological pattern. Procedia-Social and Behavioral Sciences, 174, 1371-1378.

Çilenti, K. (1985). Fen eğitimi teknolojisi [Science education technology]. Ankara: Kadıŏlu Publications.

Domin, D. S. (1999). A content analysis of general chemistry laboratory manuals for evidence of higher-order cognitive tasks. Journal of Chemical Education, 76(1), 109-111.

Ekici, G. (1996). Biyoloji öğretmenlerinin öğretiminde kullandıkları yöntemler ve karşslaştıkları sorunlar [The aim of this study is to determine the methods used by biology teachers in biology education and the problems they experience]. Masters Dissertation, Ankara University, Ankara.

Erişti-Bedir, D. S., \& Akbulut-Tekin, S. A. (2014). Anadolu üniversitesi endüstriyel sanatlar yüksekokulu modatasarımı bölümü öğrencileri örneğinde sanatsal tasarım ürünlerine dayalı kültür algısı [Culture perception 
through artistic design process at the sample of anadolu university fashion design department students]. Journal of Qualitative Research in Education, 2(1), 9-37.

Feyzioğlu, B., Demirbağ, B., Ateş, A., Çobanoğlu, İ., \& Altun, E. (2011). Kimya öğretmenlerinin laboratuvar uygulamalarına yönelik algıları: İzmir ili örneği [Chemistry teachers' perceptions on laboratory applications: Izmir sample]. Educational Sciences: Theory\& Practice, 11(2), 1005-1029.

Garnett, P. J., Garnett, P. J., \& Hackling, M. W. (1995). Refocusing the chemistry lab: a case for laboratory-based investigations. Australian Science Teachers Journal, 41(2), 26-32.

Garnett, P. J., \& O'Loughlin, M. O. (1989). Using practical tests to assess laboratory work in chemistry. Australian Science Teachers Journal, 35(4), 27-37.

Goldstein, L. B. (2005). Becoming a teacher as a hero's journey: Using metaphor in pre-service teacher education. Teacher Education Quarterly, 32(1), 7-24.

Gunstone, R. F., \& Champagne, A. B. (1990). Promoting conceptual change in the laboratory. In E. HegartyHazel (Ed.), The student laboratory and the science curriculum (pp. 159-182). London: Routledge.

Güneş, H. M., Şener, N., Germi, T. N., \& Can, N. (2013). Fen ve teknoloji dersinde laboratuvar kullanımına yönelik öğretmen ve öğrenci değerlendirmeleri [Teacher and student assessments regarding to use of science and technology laboratory]. Dicle University Journal of Ziya Gokalp Faculty of Education, 20, 1-11.

Halloun, I. (1997). Schematic concepts for schematic models of the real world: The Newtonian concept of force. Department Of Physics \& Astronomy, Arizona State University, Box 871504, Tempe, AZ 85287- 1504, USA.

Hodson, D. (1988). Experiments in science and science teaching. Educational Philosophy and Theory, 2, 53-66.

Hofstein, A. (2004). The laboratory in chemistry education: thirty years of experience with developments, implementation and research. Chemistry Education: Research and Practice 5(3), 247-264.

Hofstein, A., \& Lunetta, V. N. (1982). The role of the laboratory in science teaching: Neglected aspects of research. Review of Educational Research, 52, 2, 201-217.

Hofstein, A., \& Lunetta. V. N. (2003). The laboratory in science education: Foundations for the Twenty-First Century. Science Education, 88(1), 28-54.

Hofstein, A., Navon, O., Kipnis, M., \& Mamlok-Naaman, R. (2005).Developing students' ability to ask more and better questions resulting from inquiry-type chemistry laboratories. Journal of Research in Science Teaching, 42, 791-806.

Hofstein, A., \& Naaman, R. M. (2007). The laboratory in science education: The state of the art. Chemistry Education Research and Practice, 8(2), 105-107.

Hofstein, A., Shore, R., \& Kipnis, M. (2004). Providing high school chemistry students with opportunities to develop learning skills in an inquiry-type laboratory: A case study. International Journal of Science Education, 26, 47-62.

Kesercioğlu T., \& Aydoğdu M. (2005). İlköğretimde fen ve teknoloji ögretimi [Teaching science and technology in primary education]. Ankara: An1 Publications.

Lawson, A. E. (1995). Science teaching and the development of thinking. Wadsworth Press, California.

Miles. M. B., \& Huberman, A. M. (1994). An expanded source book qualitative data analysis. Thousand Oaks, California: Sage Publications.

Patton, M. Q. (1997). How to use qualitative methods in evaluation. Newbury park, CA: Sage.

Patton, M. Q. (2014). Nitel araştırmada çeşitlilik, kuramsal yönelimler [Diversity in qualitative research, theoretical orientations]. M. Bütün\& S. B. Beşir (Ed.). Within qualitative research and evaluation methods (pp. 75-142). Ankara: Pegem Academy Publications.

Pickering, M. (1980). Are lab courses a waste of time?. The Chronicle of Higher Education, 19, 80. 
Saban, A. (2009). Prospevtive teachers' mental images about the concept of students. The Journal of Turkish Educational Sciences, 7(2), 281-326.

Sarı, M. (2013). İlköğretim fen ve teknoloji dersinde yer alan fizik konularının öğretiminde laboratuvarın yeri ve basit araç-gereçlerle yapılan fizik deneylerinin öğretmen adaylarının görüşlerinden yararlanarak değerlendirilmesi [Call center located in the teaching of physics topics in science and technology lab in the physics experiments and simple tool-instrument taking advantage of evaluation of teacher candidates' views]. Journal of Research in Education and Teaching, 2(2), 115-121.

Şahin-Pekmez, E. (2001). Fen öğretmenlerinin bilimsel süreçler hakkındaki bilgilerinin saptanması [Identification of science teachers' knowledge of scientific processes]. Beginning of the New Millennium Science Education Symposium in Turkey this year, Maltepe University, İstanbul.

Tatar, N., Korkmaz, H., \& Ören, F. Ş. (2007). Araştırmaya dayalı fen laboratuvarlarında bilimsel süreç becerilerini geliştirmede etkili araçlar: Vee ve I Diyagramları [Effective tools to develop scientific process skills in research-based science laboratories]. Elementary Education Online, 6(1), 76-92.

Tobin, K. G. (1990). Research on science laboratory activities: In pursuit of better questions and answers to improve learning. School Science and Mathematics, 90, 403-418.

Woolnough, B. (Ed.), (1991). Practical science. Milton Keyes: Open University Press.

Yalım, H. İ. (2002) Öğretim teknolojileri ve materyal gelişstirme [Teaching technologies and material development ]. Ankara: Nobel Publications.

Yenice, N. (2005). İlköğretim fen ve teknoloji eğitiminde laboratuvar uygulama ve yöntemleri. M. Aydoğdu ve T. Kesercioğlu (Ed.). Illkögretimde fen ve teknoloji ögretimi [Teaching science and technology in primary education]. Ankara: Anı Publications.

Yıldırım, A., \& Şimşek, H. (2013). Sosyal bilimlerde nitel araştırma yöntemleri [Qualitative research methods in the social sciences]. Ankara: Seçkin Publications. 